
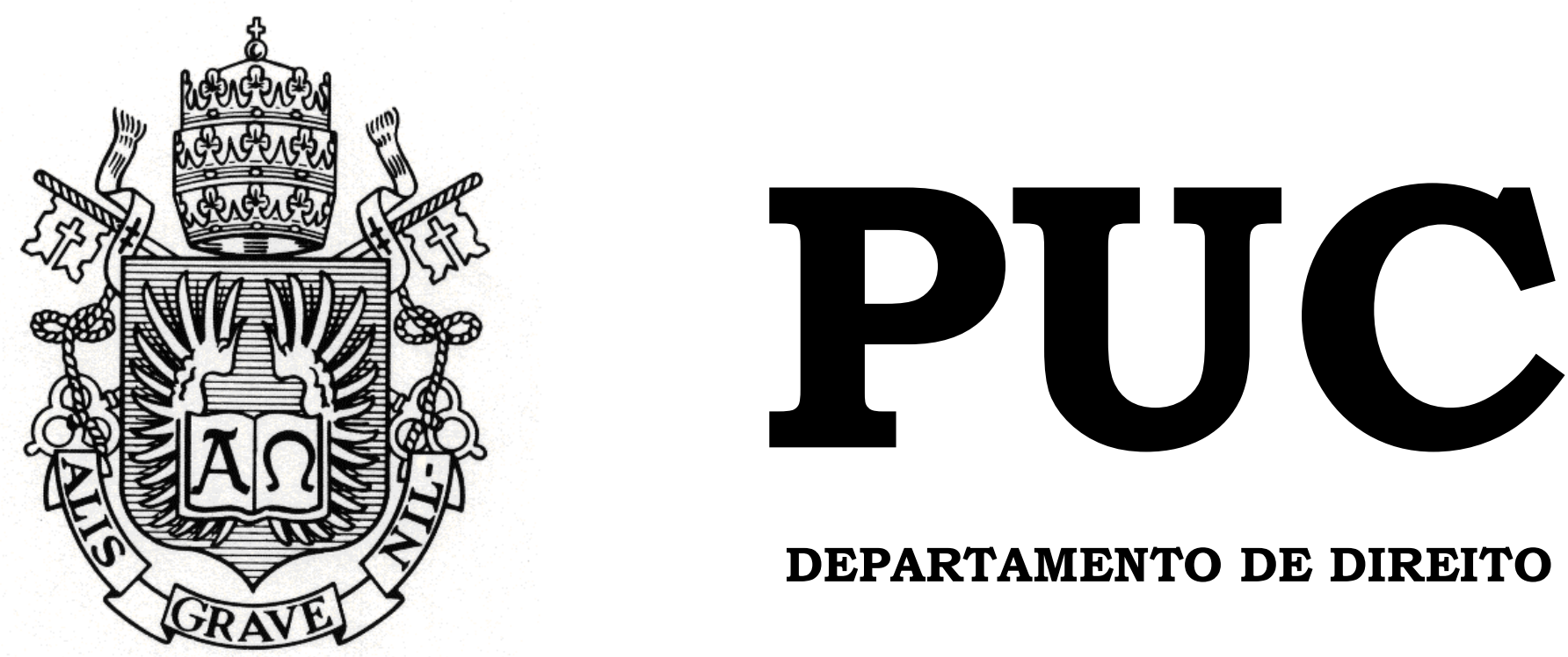

DEPARTAMENTO DE DIREITO

\title{
CONTRIBUIÇÃO DE RUI BARBOSA A UMA ORDEM MUNDIAL DEMOCRÁTICA
}

por

Brenda Maria Ramos Araújo

ORIENTADOR(A): Nádia de Araújo

2013.1

PONTIFÍCIA UNIVERSIDADE CATÓLICA DO RIO DE JANEIRO

RUA MARQUÊS DE SÃO VICENTE, 225 - CEP 22453-900

RIO DE JANEIRO - BRASIL 


\title{
CONTRIBUIÇÃO DE RUI BARBOSA A UMA ORDEM MUNDIAL DEMOCRÁTICA
}

\author{
por \\ Brenda Maria Ramos Araújo
}

Monografia apresentada ao

Departamento de Direito da Pontificia Universidade Católica do Rio de Janeiro (PUC-Rio) como requisito parcial para obtenção do título de Bacharel em Direito.

Orientadora: Nádia de Araújo 
Singela homenagem aos

90 anos de morte de Rui Barbosa de Oliveira. 


\section{AGRADECIMENTOS}

Agradeço a Nádia de Araújo, orientadora desta monografia, a atenção e os ensinamentos prestados que possibilitaram a elaboração deste estudo.

Agradeço a Marcelo Ramos Araújo sua confiança e seu apoio indispensáveis. 


\section{RESUMO}

Esta monografia analisa a atuação de Rui Barbosa na Conferência de Paz da Haia de 1907, demonstrando a relevância de seus discursos para o estabelecimento do princípio da igualdade jurídica dos Estados, para a defesa dos interesses do Brasil perante outras nações, para o fortalecimento do Direito Internacional, para a formação da Corte Internacional de Justiça e para o processo de democratização da sociedade internacional.

Após introduzir conceitos fundamentais de Direito e de Teoria das Relações Internacionais, bem como apresentar o contexto histórico em que teve lugar a Conferência de 1907, tanto no Brasil como no mundo, examinam-se trechos dos discursos de Rui Barbosa, livremente traduzidos do original em francês, com vistas a recuperar sua trajetória no decorrer da Conferência, desde o início conturbado até o final glorioso.

O estudo objetiva comprovar a permanente importância da atuação de Rui Barbosa naquela Conferência para o posicionamento do Brasil em suas relações internacionais, principalmente no que concerne aos esforços para a construção de uma ordem mundial democrática.

Palavras-chave: democracia; Direito Internacional; ordem internacional; Organizações Internacionais; princípio da igualdade dos Estados; Relações Internacionais; Rui Barbosa. 


\section{SUMÁRIO}

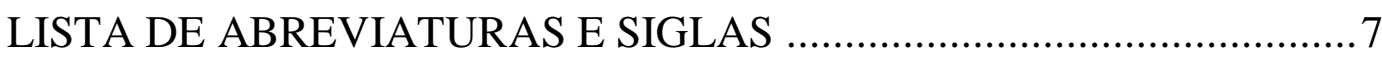

INTRODUÇÃO

PARTE I - A CAMINHO DA HAIA - CONCEITOS INICIAIS

CAPÍTULO 1 - A SOCIEDADE INTERNACIONAL E O DIREITO

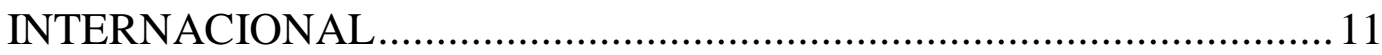

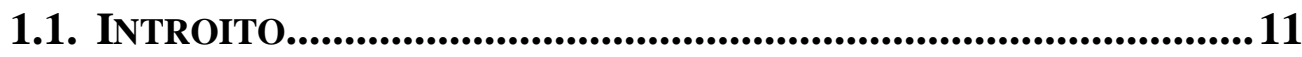

1.2. A IMPORTÂNCIA dA CONFERÊNCIA DE 1907 NA FORMAÇÃO DA SOCIEDADE INTERNACIONAL E DO DIREITO INTERNACIONAL ..........16

1.2.1. A SOCIEDADE INTERNACIONAL UNIVERSAL ............................16

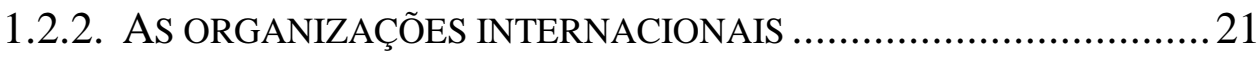

1.2.2.1. A LIGA DAS NAÇÕES ....................................................22

1.2.2.2. A CORTE PERMANENTE DE JUSTIÇA INTERNACIONAL 22

1.2.2.3. A ORGANIZAÇão das NAÇões UNIDAS E A CORTE

INTERNACIONAL DE JUSTIÇA..........................................................24

1.2.3. AS FONTES DO DIREITO INTERNACIONAL ..............................26

1.3. ConClusões PReliminares..............................................27

CAPÍTULO 2 - AS RELAÇÕES INTERNACIONAIS NO COMEÇO DO

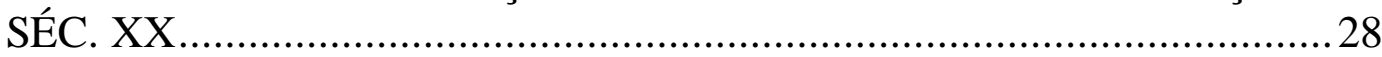

2.1. O ConTEXTo Histórico Mundial ...........................................28

2.2. O CONTEXTO HISTÓRICO BRASILEIRO...................................32

PARTE II - RUI BARBOSA E A CONFERÊNCIA DA HAIA DE 1907

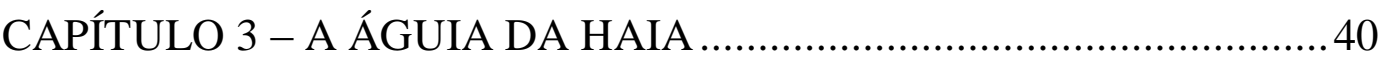

3.1. A ESCOLHA Do DELEgado do BRASIl PARA A CONFERÊNCIA DE PAZ DA HAIA DE 1907 .....................................................................41

3.2. A CONFERÊNCIA DE PAZ dA HAIA de 1907 ...............................45

3.2.1. O INCIDENTE MARTENS ..................................................... 48

3.2.2. A DOUTRINA DRAGO E A CONVENÇÃO PORTER ....................51 
3.2.3. O TRIBUNAL DE PRESAS ................................................ 53

3.2.4. A CORTE PERMANENTE DE JUSTIÇA ARBITRAL ....................56

CAPÍTULO 4 - O LEGADO DE RUI BARBOSA PARA UMA ORDEM MUNDIAL DEMOCRÁTICA.........................................................56

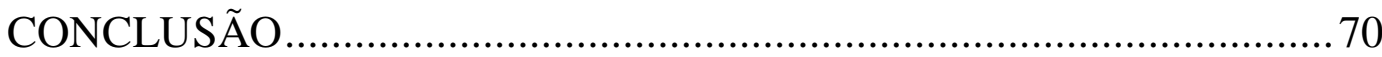

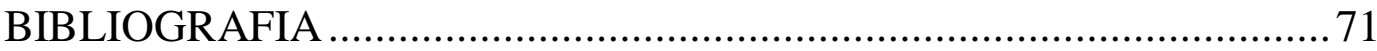

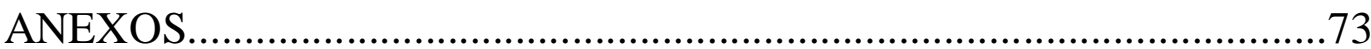




\section{LISTA DE ABREVIATURAS E SIGLAS}

$\begin{array}{ll}\text { Art. } & \text { Artigo } \\ \text { CIJ } & \text { Corte Internacional de Justiça } \\ \text { Ed. } & \text { Edição } \\ \text { EUA } & \text { Organização das Nações Unidas } \\ \text { ONU } & \\ \text { Vol. } & \text { Volume }\end{array}$




\section{INTRODUÇÃO}

O objeto desta monografia é a atuação de Rui Barbosa ao longo da Segunda Conferência de Paz da Haia de 1907.

As grandes potências do início do século XX, acostumadas a subjugar povos e explorar colônias, atuavam em função de seus próprios interesses, muitas vezes à revelia dos princípios do Direito Internacional. Durante a Conferência, Rui Barbosa foi o defensor dos países mais fracos, que iniciavam sua atuação na comunidade internacional, como o Brasil. Utilizando-se apenas da palavra, o jurista brasileiro conseguiu fazer prevalecer, naquele Parlamento das nações, o princípio da igualdade jurídica dos Estados. Essa primeira vitória, em uma conferência universal, do princípio que assegura direitos e deveres iguais a todos os países é um fato histórico de grande importância, que merece estudo detalhado.

O princípio da igualdade jurídica dos Estados é a base para a construção de uma ordem mundial democrática. Apesar de comumente aceito na doutrina como uma das fontes do Direito Internacional, esse princípio ainda é profundamente desrespeitado entre as nações. Hoje, os países em desenvolvimento continuam lutando por condições mais igualitárias na comunidade internacional. A atuação de Rui Barbosa na Conferência de Paz de 1907 é precedente relevante para esse pleito.

O presente estudo foi divido em duas partes. Na primeira, de natureza introdutória, desenvolvem-se, no Capítulo 1, conceitos de Direito Internacional e, no Capítulo 2, realiza-se breve contextualização histórica, no Brasil e no mundo. O contexto histórico é fundamental, pois possibilita 
melhor compreensão das posições que foram tomadas pelos Estados participantes da Conferência.

Na segunda parte, analisa-se, no Capítulo 3, a atuação de Rui Barbosa na Conferência, destacando-se, mediante análise de trechos de suas intervenções, aqueles momentos em que o jurista realizou defesa cabal do princípio da igualdade dos Estados. No Capítulo 4, ressalta-se a atualidade do legado de Rui Barbosa para as relações internacionais e para a política externa brasileira, em especial, no contexto de negociação de propostas de reforma do Conselho de Segurança da Organização das Nações Unidas.

A pesquisa realizada para esta monografia baseia-se em fontes primárias e secundárias. Aquelas foram obtidas junto ao arquivo histórico do Palácio do Itamaraty e ao arquivo histórico da Fundação Casa de Rui Barbosa. Estas foram obtidas na doutrina nacional e estrangeira. 
PARTE I - A CAMINHO DA HAIA - CONCEITOS INICIAIS 


\section{CAPÍTULO 1 - A SOCIEDADE INTERNACIONAL E O DIREITO INTERNACIONAL}

\subsection{Introito}

O conceito de ordem mundial democrática implica, naturalmente, o estabelecimento de analogia ou transposição de seu objeto original, i.e., o governo nacional, para a sociedade global dos Estados soberanos. Em uma ordem mundial que pudesse ser qualificada como democrática, todos os Estados teriam direitos e deveres iguais. A todas as nações do globo competiriam, portanto, a mesma oportunidade e o mesmo dever de contribuir para a manutenção e promoção da ordem mundial. Para compreender o alcance e o significado da contribuição de Rui Barbosa para tal ordem, consubstanciada especialmente por seu desempenho como delegado do Brasil à Conferência de Paz da Haia de 1907, é preciso tomar como ponto de partida alguns conceitos basilares do Direito Internacional.

O Direito tem como uma de suas características fundamentais a socialidade $^{1}$, ou seja, é um fato ou fenômeno social. Conforme reza o conhecido brocardo: ubi societas, ibi jus (onde está a sociedade, está o direito). A relação entre Direito e sociedade é dinâmica e marcada por influências recíprocas. Da mesma forma que não existe Direito sem sociedade, não podemos conceber uma sociedade sem Direito, pois este responde à necessidade de uma convivência social ordenada. Esta lição

\footnotetext{
1 "O Direito é, por conseguinte, um fato ou fenômeno social; não existe senão na sociedade e não pode ser concebido fora dela. Uma das características da realidade jurídica é, como se vê, a sua socialidade, a sua qualidade de ser social.” REALE, Miguel. Lições Preliminares de Direito. $25^{\mathrm{a}}$ ed. $22^{\mathrm{a}}$ tiragem. São Paulo: Saraiva, 2001. p.2.
} 
pode ser verificada na própria etimologia da palavra "lei", que remete a ligação ou relação, assim como a da palavra jus, que remete à ideia de coordenar, unir.

Quando o objeto de estudo é a sociedade mundial dos Estados soberanos, contudo, é fundamental ter em mente que, ao contrário do que ocorre no plano interno, a sociedade internacional é descentralizada, carecendo de autoridade superior e de milícia permanente que garanta a ordem. Nesse ambiente, organizado horizontalmente e desprovido de qualquer hierarquia, só o princípio da coordenação entre os diversos entes soberanos poderá garantir a ordem. Esta característica de descentralização influencia de diversas formas o Direito Internacional, e confere-lhe aspectos singulares quando comparado ao Direito interno ${ }^{2}$.

De forma inevitável, conclui-se que é tarefa dos próprios Estados criar e submeter-se às leis que a eles serão aplicáveis. Assim, não obstante outras teorias, consideraremos como fundamento do Direito Internacional público, também chamado de direito das nações ou direito das gentes, a teoria do consentimento das nações. Essa concepção adotada pela doutrina inglesa e pela teoria voluntarista do Direito Internacional, estabelece que é o

\footnotetext{
${ }^{2}$ Veja-se, a respeito, José Francisco Rezek: “A sociedade internacional, ao contrário do que sucede com as comunidades nacionais organizadas sob a forma de Estados, é ainda hoje descentralizada, e o será provavelmente por muito tempo adiante de nossa época." REZEK, Jose Francisco. Direito Internacional público: curso elementar. 10. ed.. São Paulo: Saraiva, 2005. p. 1. Manifesta-se, no mesmo sentido, Hildebrando Accioly: "A descentralização do poder é característica da sociedade internacional. Não há centro mundial político-jurídico, com poderes para agir, quer como legislativo, quer como executivo, quer como judiciário, acima dos entes estatais que compõem o sistema internacional." ACCIOLY, Hildebrando Pompeu. Manual de Direito Internacional público. 19. ed. São Paulo: Saraiva, 2011. 945 p.
} 
consentimento, seja de forma expressa (tratados e convenções) ou implícita (direito consuetudinário), que fundamenta o Direito Internacional. ${ }^{3}$

Assim, segundo a teoria voluntarista, adotada como premissa nesta monografia, os países pautarão sua atuação apenas de acordo com as normas jurídicas com as quais consentiram previamente. Da mesma forma, só poderá ser imposta a autoridade de um foro judiciário ou arbitral ao Estado que assim concordar. Além disso, a hierarquia entre as normas de Direito Internacional público depende exclusivamente de análises e considerações políticas adotadas pelos Estados soberanos ${ }^{4}$.

Outra conclusão é que, no âmbito internacional, o sistema de sanções decorrentes de atos ilícitos é mais precário e deficiente do que no ordenamento interno. Essa característica torna-se particularmente evidente diante das diferenças de poder entre os Estados. Ao lado do princípio da igualdade soberana está a desigualdade de fato dos Estados, decorrência inevitável das diferenças de poder, seja militar, econômico ou geopolítico. É quase impossível imaginar, por exemplo, que qualquer sanção possa ser

3 Veja-se, nesse sentido, José Francisco Rezek: "Os povos - assim compreendidas as comunidades nacionais, e acaso, ao sabor da história, conjuntos ou frações de tais comunidades propendem, naturalmente, à autodeterminação. Organizam-se, tão cedo quanto podem, sob a forma de Estados, e ingressam numa comunidade internacional carente de estrutura centralizada. Tais as circunstâncias, é compreensível que os Estados não se subordinem senão ao direito que livremente reconheceram ou construíram.” REZEK, Jose Francisco. Direito Internacional público: curso elementar. 10. ed.. São Paulo: Saraiva, 2005. p.3.

${ }^{4}$ Dessa forma, os Estados que ratificaram a Convenção de Viena sobre Direito dos Tratados de 1969, aceitam a existência de normas imperativas que são hierarquicamente superiores. Ressalta-se que o Brasil ratificou essa convenção em 2009. Sobre a importância da política no Direito Internacional, argumenta Celso D. de Albuquerque Mello: "A política é a constante do mundo internacional em maior grau do que ocorre no direito interno, acarretando modificações constantes no Direito Internacional Público, o que o torna difícil de ser estudado pelo jurista, resultando na necessidade de uma constante atualização." MELLO, Celso D. de Albuquerque. Curso de Direito Internacional público. 14. ed. v.1. Rio de Janeiro : Renovar, 2002. p.47. 
aplicada contra um dos cinco países que detêm o poder de veto no Conselho de Segurança da Organização das Nações Unidas (ONU). Nas palavras do teórico australiano de relações internacionais, Hedley Bull (1932-1985):

\begin{abstract}
"Na sociedade internacional moderna, como no estado de natureza de Locke, não há uma autoridade central capaz de interpretar e aplicar a lei, e assim os indivíduos que dela participam precisam eles próprios julgar e aplicá-la. Como em tal sociedade cada participante é um juiz em causa própria, e como a opinião dos que pretendem aplicar a lei nem sempre prevalece, a justiça nessa sociedade é rústica e incerta. No entanto, há uma grande diferença entre essa forma rudimentar de vida social e a total ausência de ordem."
\end{abstract}

Diante do exposto, a sociedade internacional poderia ser qualificada como uma "sociedade anárquica". Esta expressão, consagrada pelo cientista político inglês Goldsworthy Lowes Dickinson (1862-1932) em seus livros The European Anarchy (1916) e The International Anarchy, 1904-1914 (1926), não deve, contudo, ser confundida com a prevalência na sociedade internacional de um "estado hobbesiano" ou "estado de natureza". Essas concepções, que Thomas Hobbes (1588-1679) descreveu em seu clássico Leviathan (1651) com a expressão latina bellum omnium contra omnes (luta de todos contra todos), referem-se antes a uma sociedade marcada pela absoluta ausência de respeito e temor em relação a um poder ordenador superior.

Na linha defendida por Hedley Bull na citação acima, não haveria na sociedade internacional absoluta ausência de ordem. Deve-se levar em conta que os Estados apresentam características muito distintas dos

${ }^{5}$ BULL, Hedley. A sociedade anárquica: Um estudo da ordem na política mundial. Brasília: Editora Universidade de Brasília, Instituto de Pesquisa de Relações Internacionais; São Paulo: Imprensa Oficial do Estado de São Paulo, 2002. p.60. 
indivíduos. É preciso, portanto, ter muito cuidado ao empregar a analogia do "estado de natureza". Nesse sentido, é que defende Bull que, à diferença dos indivíduos, os Estados seriam capazes de formar uma sociedade sem governo, dotada de uma certa ordem, ainda que rudimentar. ${ }^{6}$

A ordem internacional existe, sobretudo, por causa de certos valores compartilhados e do interesse comum dos Estados no progresso da humanidade, na realização dos objetivos elementares da vida social - a limitação do uso da violência, a segurança de que os acordos serão cumpridos, a existência de um direito de propriedade.

Nesse contexto, conclui-se que o Direito Internacional pode ser considerado um dos fatores fundamentais para a manutenção da ordem no plano internacional. É, por sinal, fator que evoluiu consideravelmente ao longo do século $\mathrm{XX}$ em conjunto com a própria sociedade internacional. $\mathrm{O}$ Direito Internacional contribui para garantir a paz e prover essa "sociedade anárquica" de um mínimo de normas essenciais que ajudam a desenvolvê-la e a mantê-la.

\footnotetext{
6 "Assim, o argumento de que porque os indivíduos não podem formar uma sociedade sem governo, os príncipes soberanos ou estados também não podem, não se sustenta não apenas porque mesmo na ausência de governo pode haver uma certa ordem entre os indivíduos mas porque os estados são diferentes destes, e mais capazes de formar uma sociedade anárquica. A analogia do meio internacional com a ordem doméstica não passa de uma analogia, e o fato de que os estados formam uma sociedade sem governo reflete características da sua condição que são únicas." BULL, Hedley. A sociedade anárquica: Um estudo da ordem na política mundial. Brasília: Editora Universidade de Brasília, Instituto de Pesquisa de Relações Internacionais; São Paulo: Imprensa Oficial do Estado de São Paulo, 2002. p.62.
} 


\subsection{A importância da Conferência de 1907 na formação da sociedade internacional e do Direito Internacional}

Foi no século XX, mais precisamente logo após a Segunda Guerra Mundial, que uma sociedade internacional de dimensões globais, tal como conhecida no presente, consolidou-se. Em sua formação, a Conferência de Paz da Haia de 1907 desempenhou papel crucial. Resultam daquela Conferência o embrião da Corte Internacional de Justiça (CIJ) e das organizações universais, que após a fracassada experiência da Liga das Nações, têm na ONU uma história que já dura quase 70 anos.

Ao longo desta monografia elabora-se análise da importância da Conferência de 1907 na formação da sociedade internacional do início do século XXI e, por correspondência, do Direito Internacional dos dias atuais, uma vez que, como examinado no início deste capítulo, é na sociedade internacional que surge o ordenamento jurídico internacional.

\subsubsection{A sociedade internacional universal}

Para Hedley Bull, o processo histórico de formação de uma sociedade internacional de dimensões globais, ou universais, teve início como consequência da expansão dos Estados europeus a partir do fim do século $\mathrm{XV}$, quando foram a ela agregados os sistemas internacionais regionais Árabe-Islâmico, Indiano, Tártaro-Mongol e Chinês. Os sistemas regionais funcionavam, antes da formação de um sistema universal, de modo inteiramente independente entre si, pois cada qual possuía regras e instituições distintas, definidas pela cultura regional dominante. 
No fim do século XVIII e inícios do século XIX, a sociedade internacional europeia expande-se geograficamente, projetando seu poder no mundo inteiro. Ao representar a vitória absoluta de imigrantes europeus sobre povos indígenas originais, as independências dos Estados Unidos da América (EUA), do Brasil e das colônias hispânicas nas Américas marca o triunfo da sociedade europeia no Novo Continente. As grandes conferências multilaterais realizadas ao longo do século $\mathrm{XIX}^{7}$, culminando na Conferência da Haia de 1907, também refletem esse processo de formação de uma sociedade universal de Estados soberanos, com progressiva participação de países de todo o mundo no processo de codificação do direito das gentes. É nesse sentido que a Conferência de 1907 pode ser considerada verdadeira antecipação da Assembleia Geral das Nações Unidas $^{8}$.

\footnotetext{
7 “A segunda metade do século XIX foi assinalada por vários fatos favoráveis ao progresso do Direito Internacional, podendo-se mencionar o Congresso de Paris, de 1856; a $1^{\text {a }}$ Convenção da Cruz Vermelha, em 1864; a Declaração de 1868, contra projéteis explosivos ou inflamáveis; o Congresso de Berlim, de 1878; a Conferência Africana de Berlim, de 1884-1885; a Conferência de Bruxelas, de 1889-1890, contra o tráfico de escravos; a $1^{\text {a }}$ Conferência Internacional dos Países Americanos, realizada em Washington, de outubro de 1889 a abril de 1890; a $1^{\text {a }}$ Conferência da Paz, de Haia, em 1899." ACCIOLY, Hildebrando Pompeu. Manual de Direito Internacional público. 19. ed. São Paulo: Saraiva, 2011. p. 109. Além das conferências mencionadas por Accioly, acrescentamos o Congresso de Viena de 1815 para completar o grupo das grandes conferências do século XIX.

8 "No Congresso de Viena de 1815 só estiveram presentes Estados europeus, mas na Conferência de Paz de Paris de 1856 o Império Otomano esteve representado; na Conferência da Haia de 1899, juntos com Estados Unidos e México, estiveram presentes o Império Otomano, China, Japão, Pérsia e Sião; e na Conferência da Haia de 1907 estiveram presentes um total de dezesseis repúblicas latino-americanas, cujo considerável impacto foi a premonição da influência do Terceiro Mundo na Assembléia Geral das Nações Unidas. Por ocasião da Primeira Guerra Mundial, então, já existia claramente uma sociedade internacional universal de Estados cobrindo a totalidade do mundo e que incluía Estados representativos das Américas, Ásia e África, assim como da Europa." BULL, Hedley; WATSON, Adam. The Expansion of international society. Oxford : Clarendon Press, c1984. p.123.
} 
Aquela Conferência, ao contar com a participação de delegações de todos os continentes livres, representou importante passo para a universalização da sociedade internacional. ${ }^{9}$ Sua influência foi, no entanto, muito além da consolidação de uma sociedade global. O papel nela desempenhado pelo Brasil e a prevalência do princípio da igualdade entre os Estados prenunciam a longa luta dos países em desenvolvimento por garantir sua influência na conformação da sociedade global, i.e., na constituição da ordem internacional.

A sociedade internacional universal, consolidada após a Segunda Guerra Mundial, formou-se ao longo dos séculos XIX e XX por um processo que Hedley Bull denomina "A Revolta contra o Ocidente". Esse processo pode ser dividido em cinco temas: a luta pela igualdade soberana dos Estados; a revolução anticolonial; a luta em favor da igualdade racial; a luta contra a injustiça econômica; e a luta pela libertação cultural. Para esta monografia, o primeiro tema será o mais relevante.

A luta pela igualdade soberana tinha como alvo conceder aos países não-europeus algo além de uma independência meramente formal. A motivação principal dessa "revolta contra o Ocidente" era o princípio da igualdade jurídica dos Estados. A luta envolvia, em sua origem, a

9 Nesse sentido, veja-se: "Quando os delegados se reuniram no Binnenhof de Haia, encontravam-se representados todos os governos independentes do mundo, à exceção da Abissínia - cujo imperador recusou enviar representante -, da Libéria e do Marrocos - que não foram convidados -, e de Honduras e da Costa Rica - que não enviaram delegados. Os russos representavam a Rússia e Montenegro, bem como Colômbia e São Salvador tinham o mesmo representante. Estavam presentes ao todo 44 Estados, representados por mais de duzentos delegados. Era a conferência internacional que reunia o maior número de emissários até então." MUNIZ, Adam Jayme. Águia na Haia: olhar geral sobre a participação brasileira na II Conferência de Paz. Juca: A revista dos alunos do Instituto Rio Branco. Brasília, nº 01, 2007. pp.18, 19. 
dissolução dos chamados tratados desiguais ${ }^{10}$, que, firmados por coação militar ou econômica, limitavam a soberania dos Estados não-europeus. Eram confrontados, em primeiro lugar, aqueles tratados desiguais que garantiam jurisdição extraterritorial aos cidadãos europeus que residissem ou mantivessem relações econômico-comerciais em territórios nãoeuropeus.

O princípio da igualdade dos Estados é fundamental para a defesa da soberania e sem ele é impossível conceber qualquer organismo de Direito Internacional $^{11}$. Sua origem remonta ao Tratado de Paz de Vestefália, de 1648, que ao por fim à Guerra dos Trinta Anos, não levou em consideração diferenças de confissão religiosa ou de regime político entre os signatários, que incluíam Espanha, França, Holanda, Suécia e o Sacro-Império Romano-Germânico. O princípio só viria a estabelecer-se de forma definitiva na vida internacional, entretanto, depois da primeira fase de transição para a sociedade global, entre o último quartel do século XIX e a primeira metade do século XX.

${ }^{10}$ Cite-se como exemplo de tratado desigual envolvendo o Brasil o Tratado de Navegação e Comércio, assinado em 1810 e renovado em 1827, com a Inglaterra. Esse tratado trazia uma serie de garantias comerciais para os ingleses, deixando, em grande parte, o comércio brasileiro em suas mãos. O art. $9^{\circ}$ estabelecia o cargo de "Juiz Conservador da Nação Inglesa". A ele, exclusivamente, competia julgar todas as causas que fossem apresentadas por vassalos britânicos residindo no Brasil. Esses "Magistrados Conservadores" eram eleitos pelos britânicos que residiam ou comerciavam na cidade e a escolha era depois ratificada pelo Príncipe Regente. Os vassalos britânicos tinham também garantida a inviolabilidade de domicilio.

${ }^{11}$ Nesse sentido, veja-se: "Nesse discurso, Rui defendeu, com veemência, o princípio da igualdade jurídica dos Estados, onde 'sem este ponto de partida, não haveria razão para existir qualquer organismo de Direito Internacional' (Mendes Silva 2003: 116).” VISENTINI, Paulo Fagundes. "A Águia de Haia": Rui Barbosa Diplomata. In: NAGLE, Marilene; WIESEBRON, Marianne L. (Orgs.). Rui Barbosa: uma personalidade multifacetada. Brasília: FUNAG, 2012. p. 52. 
Dão exemplos históricos da defesa do princípio da igualdade a atuação diplomática dos seguintes países: Brasil, ao denunciar o Tratado de Navegação e Comércio com a Inglaterra, em 1844; Japão, nos anos de 1890; Turquia, no Tratado de Lausanne de 1923; Egito, por meio do Tratado Anglo-Egípcio de 1936; e China, mediante acordo com os Estados Unidos e a Inglaterra, em 1943.

Foi durante a Conferência de 1907, no entanto, em contexto que envolveu países de todo o mundo, que o princípio da igualdade entre os Estados teve sua primeira vitória de alcance mundial ${ }^{12}$. Esse princípio, defendido por Rui Barbosa na mencionada Conferência, - conforme se examinará em maior profundidade mais adiante -, é o fundamento de uma ordem internacional democrática e legítima, que preside hoje as propostas de reforma do Conselho de Segurança da ONU.

As violações ao princípio da igualdade permanecem na ordem internacional contemporânea. Basta recordar que os cinco membros permanentes do Conselho de Segurança da ONU - EUA, Rússia, Reino Unido, França e China - ainda possuem o direito exclusivo de veto, ou seja, podem bloquear as decisões tomadas pela maioria dos membros do Conselho $^{13}$. A reforma do Conselho de Segurança da ONU será examinada

\footnotetext{
12 "Rui foi um visionário. Apenas com o poder da palavra, ajudou a construir as bases da doutrina que conduziria à aceitação universal do princípio da igualdade jurídica dos Estados, um dos pilares do multilateralismo contemporâneo." AMORIM, Celso. A diplomacia multilateral do Brasil: um tributo a Rui Barbosa. Brasília: Fundação Alexandre de Gusmão, 2007. 20 p.

${ }^{13}$ Conforme esclarece Celso D. de Albuquerque Mello: "A igualdade jurídica na ordem internacional, entretanto, não é absoluta. Na carta da ONU, no Conselho de Segurança, foi dado aos cinco Grandes (EUA, URSS, Grã-Betanha, França e China) o direito de veto, o que viola o princípio da igualdade jurídica entendido estritamente, porque o voto destes Estados enumerados
} 
no capítulo IV desta monografia, à luz das contribuições de Rui Barbosa na Conferência de 1907.

\subsubsection{As organizações internacionais}

O século XX marca, também, no Direito Internacional, o início da era das organizações internacionais, em que os Estados soberanos vêm buscando, através de seu próprio consentimento, construir uma ordem jurídica internacional capaz de garantir a paz, a segurança e a justiça, submetendo-se progressivamente a um marco normativo e institucional supranacional que eles próprios vêm construindo ${ }^{14}$.

As organizações internacionais são um fenômeno recente, principalmente se comparadas aos Estados, e talvez por esse motivo, ainda não possuem uma definição em norma internacional. Apesar da grande heterogeneidade das organizações internacionais, podemos dizer que elas só começaram a se desenvolver da forma em que são conhecidas atualmente

passa a ter maior peso do que os dos demais membros." MELLO, Celso D. de Albuquerque. Curso de Direito Internacional público. 14. ed. v.1. Rio de Janeiro : Renovar, 2002. p.431.

${ }^{14}$ Segundo Celso D. de Albuquerque Mello: "A sociedade internacional dos nossos dias é completamente diversa da do século anterior em virtude de um fator principal: os Estados compreenderam que existem certos problemas que não podem ser resolvidos por eles sem a colaboração dos demais membros da sociedade internacional. As organizações internacionais são as resultantes deste fator e é dentro delas que mais se sente a atuação das ideologias ou blocos sócio-culturais nas soluções dos mais diferentes problemas. É a nossa época caracterizada como sendo a do associacionismo internacional. Este se manifesta não apenas em nível governamental com a criação de organizações intergovernamentais, cerca de 300, mas também no nível de particulares com a criação de organizações não-governamentais." MELLO, Celso D. de Albuquerque. Curso de Direito Internacional público. 14. ed. v.1. Rio de Janeiro : Renovar, 2002. p.49. 
após a criação da Liga das Nações, em 1919, com a Paz de Versailles, que pôs fim à Primeira Guerra Mundial ${ }^{15}$.

\subsubsection{A Liga das Nações}

A Liga das Nações, também conhecida como Sociedade das Nações, tinha como principal finalidade promover a cooperação internacional e assegurar a paz na sociedade internacional. Funcionou de 1920 a 1946, quando foi dissolvida e seus bens foram transferidos para a ONU, apesar de ter seu funcionamento interrompido com o início da Segunda Guerra Mundial ${ }^{16}$. A expressão "Sociedade das Nações" já era citada na Conferência da Haia de 1907.

$\mathrm{O}$ artigo XIV do Pacto da Sociedade das Nações previa a criação de uma Corte Permanente de Justiça Internacional, que seria competente para julgar qualquer disputa internacional a ela submetida pelas partes e para emitir pareceres a pedido do Conselho ou da Assembleia da Liga das Nações.

\subsubsection{A Corte Permanente de Justiça Internacional}

A Corte Permanente de Justiça Internacional foi instalada na cidade da Haia, em 1922, como um organismo autônomo da Liga das Nações. O seu Estatuto, elaborado por um Comitê de Juristas, em 1920, foi fortemente

\footnotetext{
${ }^{15}$ Nesse sentido, veja-se Celso D. de Albuquerque Mello: "As organizações internacionais, como nós a entendemos hoje (com fins políticos, modos de decisão pela maioria, com poder regulamentar e personalidade internacional, etc.), só começaram a se desenvolver após a $1^{\mathrm{a}}$ Guerra Mundial, com a criação da Liga das Nações." MELLO, Celso D. de Albuquerque. Curso de Direito Internacional público. 14. ed. v.1. Rio de Janeiro : Renovar, 2002. pp.606, 607.

${ }^{16}$ Ressalte-se que a comissão de liquidação da Liga só encerrou os seus trabalhos em 1947.
} 
influenciado pelo projeto de uma Corte Permanente de Justiça Arbitral, apresentado e debatido durante a Conferência de 1907. Àquela época, não havia sido possível aprovar o projeto, devido a divergências relacionadas ao processo de eleição dos juízes. Reconhece-se, contudo, que o projeto possuía algumas ideias fundamentais que alguns anos depois serviriam como fonte de inspiração para o Estatuto da Corte Permanente de Justiça Internacional $^{17}$.

A Corte Permanente de Justiça Arbitral, conforme concebida na Conferência da Haia, seria um tribunal permanente composto por juízes que se reuniriam anualmente para julgar os casos que lhe fossem submetidos em função de uma estipulação geral de arbitragem ou de um acordo especial. Devido a desacordo entre os Estados sobre como os juízes seriam escolhidos, porém, a Corte nunca entrou em funcionamento. A proposta brasileira, fundada no princípio da igualdade, sustentava que houvesse

${ }^{17}$ No sítio eletrônico oficial da Corte Internacional de Justiça encontra-se importante referência àquele projeto: "A few years later, in 1907, a second Hague Peace Conference, to which the States of Central and South America were also invited, revised the Convention and improved the rules governing arbitral proceedings. Some participants would have preferred the Conference not to confine itself to improving the machinery created in 1899. The United States Secretary of State, Elihu Root, had instructed the United States delegation to work towards the creation of a permanent tribunal composed of judges who were judicial officers and nothing else, who had no other occupation, and who would devote their entire time to the trial and decision of international cases by judicial methods. "These judges", wrote Secretary Root, "should be so selected from the different countries that the different systems of law and procedure and the principal languages shall be fairly represented". The United States, the United Kingdom and Germany submitted a joint proposal for a permanent court, but the Conference was unable to reach agreement upon it. It became apparent in the course of the discussions that one of the major difficulties was that of finding an acceptable way of choosing the judges, none of the proposals made having managed to command general support. The Conference confined itself to recommending that States should adopt a draft convention for the creation of a court of arbitral justice as soon as agreement was reached "respecting the selection of the judges and the constitution of the court". Although this court was never in fact to see the light of day, the draft convention that was to have given birth to it enshrined certain fundamental ideas that some years later were to serve as a source of inspiration for the drafting of the Statute of the Permanent Court of International Justice (PCIJ)." Disponível em http://www.icj-cij.org/court/index.php?p1=1\&p2=1. Acesso em 10 mar. 2013. 
tantos juízes quanto Estados-membros. As grandes potências, porém, defendiam que todos os juízes permanentes fossem escolhidos por elas, reservando às potências menores tão-somente a escolha de juízes temporários, submetidos a sistema de rotatividade.

A Corte Permanente de Justiça Internacional superou esse empecilho ao estabelecer que os juízes deveriam ser eleitos pelo Conselho e pela Assembleia Geral da Liga das Nações. No primeiro mandato de 1921 1930, Rui Barbosa foi eleito juiz da Corte. Viria, no entanto, a falecer em 1923, sem ter tido a oportunidade de participar de qualquer sessão, sendo substituído pelo ex-Presidente da República Epitácio Pessoa. No total, a Corte Permanente de Justiça Internacional julgou vinte e nove casos contenciosos entre Estados e proferiu vinte e sete pareceres consultivos.

Com o advento da Segunda Guerra Mundial, a Corte Permanente de Justiça Internacional não julgou mais nenhum caso, nem realizou as eleições para juízes. Finalmente, em 1946, com a dissolução formal da Liga das Nações, que havia falhado em cumprir com seu objetivo de evitar a guerra, todos os membros da Corte renunciaram.

\subsubsection{A Organização das Nações Unidas e a Corte Internacional de Justiça}

Já em 1945, foi realizada, em San Francisco, nos Estados Unidos, a Conferência das Nações Unidas para a Organização Internacional onde foi elaborada a Carta da Organização das Nações Unidas. A ONU foi a sucessora da Sociedade das Nações e concretizou pela primeira vez a 
institucionalização de uma ideia de governo mundial, possuindo, em 2013, cento e noventa e três Estados-membros.

A Carta da ONU, em seu artigo $7^{\circ}$, estabeleceu como o principal órgão judicial das Nações Unidas, em substituição à Corte Permanente de Justiça Internacional, a Corte Internacional de Justiça, que tem praticamente o mesmo estatuto da antiga Corte, à exceção de pequenas adaptações. $\mathrm{O}$ estatuto da Corte Internacional de Justiça é um anexo à Carta da ONU, mas é também reconhecido como um tratado autônomo que pode ser ratificado por Estados que não são membros da ONU. Segundo o art. 93, §1 ${ }^{\circ}$, da Carta da ONU, todos os Estados membros das Nações Unidas são também membros do estatuto.

A Corte Internacional de Justiça possui competência para julgar litígios entre Estados, sendo que nenhum Estado será parte de um litígio na CIJ se não houver declarado seu consentimento. São três os casos possíveis de consentimento: I- os Estados que integram o litígio fazem parte de um tratado que prevê expressamente a competência da CIJ; II- os Estados que são partes do litígio aceitam expressamente o compromisso de resolver o litígio específico pela CIJ; III- ambos os Estados que são partes no litígio aceitam, em qualquer momento, a jurisdição compulsória da CIJ para resolver litígios, conforme é estipulado pelo art. $36, \S \S 2^{\circ}$ ao $5^{\circ}$, do Estatuto $^{18}$.

\footnotetext{
${ }^{18}$ Sessenta e nove Estados, em 2013, declararam aceitar a jurisdição compulsória da CIJ. Uma lista dos países está disponível no sítio eletrônico oficial da Corte Internacional de Justiça: http://www.icj-cij.org/jurisdiction/index.php?p1=5\&p2=1\&p3=3. Acesso em 21 mai. 2013.
} 
Atualmente, a Corte Internacional de Justiça, também chamada Corte da Haia, é o mais importante tribunal judiciário da sociedade internacional.

\subsubsection{As fontes do Direito Internacional}

Por fim, saliente-se que a Conferência da Haia de 1907 buscou estabelecer, de forma pioneira, as fontes do Direito Internacional ${ }^{19}$. Ao aprimorar as regras de solução de controvérsias por meio da arbitragem, ou - de modo ainda mais inovador - ao propor a criação de um tribunal internacional permanente para julgar casos referentes a presas de guerra, a Conferência buscou codificar fontes do Direito Internacional. A preocupação com a delimitação das fontes está presente, por exemplo, no artigo $7^{\circ}$, transcrito abaixo, da Convenção que criava o Tribunal Internacional de Presas:

"Art. $7^{\circ}$ Se a questão de direito estiver prevista por uma Convenção em vigor entre o beligerante captor e a Potência que for parte do litígio ou cujo nacional for parte dele, o Tribunal (Internacional de Presas) se conformará com as estipulações da mencionada Convenção.

Não existindo essas estipulações, o Tribunal aplica as regras de Direito Internacional. Se não existirem regras geralmente reconhecidas, o Tribunal decide de acordo com os princípios gerais de direito e da eqüidade."

O Brasil não faz parte desse grupo, mas é membro do Pacto de Bogotá (Tratado Americano sobre Soluções Pacíficas), de 1948, que obriga as Partes Contratantes a resolver controvérsias por meios pacíficos e indica, entre os procedimentos a serem adotados, o recurso à Corte Internacional de Justiça de Haia. O Brasil submete-se, portanto, à jurisdição da Corte para litígios que envolvam países que ratificaram o Pacto de Bogotá.

${ }^{19}$ Hodiernamente, as fontes do Direito Internacional estão elencadas no art. 38 do Estatuto da CIJ, acrescentando-se mais duas. Elas são: I- tratados ou convenções; II- costume internacional; III- princípios gerais de direito; IV- atos unilaterais dos Estados; V- decisões ou resoluções das organizações internacionais. 


\subsection{Conclusões Preliminares}

Em virtude dos fatos mencionados, fica evidente o papel da Conferência da Haia de 1907 na formação da sociedade internacional global e no progresso do Direito Internacional, visto por Rui Barbosa como ferramenta necessária e fundamental para lidar com contexto mundial que anunciava eminente deflagração de conflitos.

O estudo da Segunda Conferência de Paz da Haia é imprescindível para a compreensão da evolução do Direito Internacional no século $X^{20}$ - é a pedra fundamental da Corte Internacional de Justiça, do universalismo e das organizações internacionais - além de marco e referência para os países emergentes, em sua luta por assegurar o direito a condições dignas de desenvolvimento e participação na ordem internacional frente aos Estados desenvolvidos ${ }^{21}$.

\footnotetext{
20 "Os jurisconsultos e os diplomatas deverão sempre estudar com muita atenção as discussões de 1907 - debates animados, acalorados, mas sempre cordiais. Entenderão, assim, a natureza das dificuldades a vencer e poderão encontrar as soluções adequadas." RENAULT, louis. L'Oeuvre de La Haye em 1899 et em 1907 - conférence faite a l'Institut Nobel a Kristiania le 18 mai 1908, Stockholm Impremerie Royale, P.-A. Norstedt \& Fils, 1908.

${ }^{21}$ A importância do estudo do Direito Internacional como instrumento para o desenvolvimento já foi assinalada por Celso D. de Albuquerque Mello: "O estudo do DIP deve vir a ser intensificado nos diferentes países, o que está conforme ao que a ONU solicitou aos seus membros em 1962, mas acima de tudo entre nós subdesenvolvidos que devemos lutar para que ele se transforme em um DI do Desenvolvimento.” (Mello, 2002, p.59)
} 


\section{CAPÍTULO 2 - AS RELAÇÕES INTERNACIONAIS NO COMEÇO DO SÉC. XX}

\subsection{O Contexto Histórico Mundial}

Entre os anos de 1875 e 1914, o cenário mundial passava por um período que o historiador inglês Eric Hobsbawm (1917-2012) chamou de "era dos impérios"22. Os países de capitalismo desenvolvido dominavam os atrasados e havia imperadores espalhados por todas as regiões do mundo ${ }^{23}$. A maior parte do planeta estava dividida em territórios dominados direta ou indiretamente por um seleto grupo de Estados, entre os quais se destacavam Grã-Bretanha, França, Estados Unidos e Japão. O planeta dividia-se cada vez mais entre fortes e fracos, avançados e atrasados. $\mathrm{O}$ imperialismo gerou uma rivalidade crescente entre os integrantes desse pequeno grupo de potências, que culminou na I Guerra Mundial em 1914. Em contraste com os horrores que assistiria o mundo durante a guerra, aquele período histórico ficou também conhecido como Belle Époque.

No final da década de 1880, iniciou-se uma corrida armamentista. Todavia, os europeus já estavam cientes da possibilidade de uma guerra generalizada desde o início da década anterior. Grandes intelectuais europeus como Friedrich Engels, Ivan Bloch e Friedrich Nietzsche já analisavam a possibilidade de uma guerra mundial. Desta forma, objetivando a paz entre as nações, realizou-se, em 1890, o Congresso

\footnotetext{
${ }^{22}$ HOBSBAWM, Eric J.. A Era dos Impérios. 13 ${ }^{\mathrm{a}}$ ed. São Paulo: Paz e Terra, 2011. 583 p.

${ }^{23}$ Até mesmo no Brasil, onde o Império durou de 1822 a 1889. Ressalte-se que Dom Pedro II foi o último imperador do continente americano.
} 
Mundial para a Paz; criou-se, em 1897, o prêmio Nobel da Paz; e reuniuse, em 1899, a I Conferência de Paz da Haia.

A Conferência de Paz de 1899, realizada entre 18 de maio e 25 de agosto, e convocada por Nicolau II, último czar russo, contou com a participação de 26 Estados, sendo que da América Latina apenas o México enviou delegados. Suas discussões mais relevantes envolveram a regulação do armamentismo e a criação de formas pacíficas de resolução de conflitos entre os Estados.

Essa conferência foi marco importante no progresso do Direito Internacional. Ela foi dividida em três comissões, que deram origem, cada qual, a uma convenção: 1) Convenção sobre as Leis e Usos da Guerra Terrestre; 2) Convenção para a Aplicação à Guerra Marítima dos Princípios da Convenção de Genebra de 22 de agosto de 1864; e 3) Convenção para a Solução Pacífica dos Conflitos Internacionais ${ }^{24}$. Ademais, por unanimidade, os Estados criaram um tribunal internacional de arbitragem na cidade da Haia, que ficou conhecido como Corte Permanente de Arbitragem da

\footnotetext{
24 “A Primeira Conferência da Paz de Haia apresentou um relevante balanço em termos de contribuições para o progresso do Direito Internacional, expressas em sua Ata Final, que englobou três convenções: 1) Convenção sobre as Leis e Usos da Guerra Terrestre; 2) Convenção para a Aplicação à Guerra Marítima dos Princípios da Convenção de Genebra de 22 de agosto de 1864; e 3) Convenção para a Solução Pacífica dos Conflitos Internacionais. Ademais, aprovou outras três declarações sobre: proibição do lançamento de projéteis e explosivos dos balões ou por outros meios semelhantes; proibição dos projéteis que tenham por fim único espalhar gases asfixiantes ou deletérios, e proibição do emprego de balas que se dilatam ou se achatam facilmente dentro do corpo humano." CARDIM, Carlos Henrique. A Raiz das Coisas: Rui Barbosa: O Brasil no Mundo. Rio de Janeiro: Civilização Brasileira, 2008. p. 105.
} 
Haia $^{25}$. Essa instituição permanece até os dias atuais e é a mais antiga organização de resolução de conflitos internacionais.

Nos anos de 1900, a guerra mundial era uma realidade cada vez mais próxima, apesar de sua deflagração não ser ainda realmente esperada. Em 1904, o Presidente dos Estados Unidos, Theodore Roosevelt (1901-1909), incumbiu o Secretário de Estado John Hay a enviar uma circular às representações dos Estados Unidos no exterior com o objetivo de convocar uma segunda conferência de paz, para tratar dos assuntos pendentes da primeira conferência ${ }^{26}$. No entanto, devido à guerra de 1904-1905 entre a Rússia e o Japão, a realização da nova conferência foi adiada.

A guerra russo-japonesa, iniciada em 5 de fevereiro de 1904, tinha como objeto de disputa os territórios da Coreia e da Manchúria. Essa guerra levou o Comandante do Estado-Maior das Forças Armadas da Alemanha a defender, sem sucesso, a realização de um ataque contra a França, tendo em vista que a principal aliada de Paris, - a Rússia -, estaria imobilizada pela

\footnotetext{
25 "Por unanimidade, as nações ali representadas decidiram criar um tribunal internacional de arbitragem, conhecido a partir daí como Corte Permanente de Haia. Ficou estabelecido que essa cidade seria a sede regular da Corte, com um corpo de juízes entre os quais cada parte de um litígio podia escolher dois árbitros, e estes quatro, por sua vez, escolheriam um quinto. Um conselho internacional composto de representantes de todos os Estados acreditados em Haia asseguraria a organização e o funcionamento da Corte.” MAGALHÃES, Rejane M. Moreira de A. Presença de Rui Barbosa em Haia. Disponível em http://www.casaruibarbosa.gov.br/dados/DOC/artigos/sobre_rui_barbosa/FCRB_RejaneMagalhae s_PresencaRuiBarbosa_em_Haia.pdf. p. 2. Acesso em 13 de mar. 2013.

26 "Em outubro de 1904, o Secretário de Estado norte-americano John Hay enviou uma circular às representações dos Estados Unidos no exterior, pedindo que fossem averiguados os sentimentos dos demais poderes mundiais com relação à convocação para uma segunda conferência. A nota baseava-se na chamada Declaração de Saint Louis, da União Interparlamentar, que pedia ao Presidente Theodore Roosevelt instar aos governos a realização da II Conferência." MUNIZ, Adam Jayme. Águia na Haia: olhar geral sobre a participação brasileira na II Conferência de Paz. Juca: A revista dos alunos do Instituto Rio Branco. Brasília, nº 01, 2007. p. 15.
} 
guerra com o Japão no oriente. A derrota dos russos conquistou aos Japoneses um lugar entre as grandes potências e foi significativa para a formação da Tríplice Entente (aliança militar entre Reino Unido, França e Rússia), em 1907, ao colocar de lado muitos receios britânicos em relação a eventual ameaça russa.

Com o final da guerra russo-japonesa e a assinatura do Tratado de Portsmouth de 1905 entre Rússia e Japão ${ }^{27}$, o caminho para a realização da segunda conferência estava aberto. Assim, o Czar Nicolau II, interessado na constituição de um órgão efetivo de manutenção da paz, procurou o Presidente Roosevelt, que concordou em ceder à Rússia a iniciativa de convocar a segunda conferência. A princípio, a conferência foi agendada pela Rússia e pelos Países Baixos para o ano de 1906, na mesma cidade da conferência de 1899, isto é, na Haia.

Todavia, a Terceira Conferência Pan-Americana ${ }^{28}$, que aconteceria no Rio de Janeiro e era considerada pelo Brasil, ao menos em parte, preparatória para a Conferência da Haia, já estava agendada para a mesma data. Por esse motivo, Joaquim Nabuco, então Embaixador do Brasil nos Estados Unidos, procurou o Secretário de Estado norte-americano

${ }^{27}$ O mediador do Tratado de Portsmouth foi o Presidente Theodore Roosevelt, que por esse feito ganhou o prêmio Nobel da paz de 1906.

28،"Duas conferências pan-americanas foram realizadas: uma, em Washington, em outubro de 1889, e outra no México, em outubro de 1901. A terceira realizou-se no Rio de Janeiro, em julho de 1906, graças aos esforços de Joaquim Nabuco, então embaixador do Brasil em Washington, embora a Argentina e a Venezuela pleiteassem tal honraria. O Presidente Theodore Roosevelt, ao reanimar a doutrina de James Monroe, "a América para os americanos", converteu o panamericanismo num dos elementos da sua política externa.” MAGALHÃES, Rejane M. Moreira de A. Presença de Rui Barbosa em Haia. Disponível em <http://www.casaruibarbosa.gov.br/dados/DOC/artigos/sobre_rui_barbosa/FCRB_RejaneMagalh aes_PresencaRuiBarbosa_em_Haia.pdf. Acesso em 13 de mar. 2013>.pp 1-3. 
requisitando o adiamento da segunda conferência de paz. O Secretário de Estado consultou as potências europeias, que também se mostraram a favor do adiamento. Respondeu, então, à Rússia que era preciso esperar o término da Terceira Conferência Pan-Americana e também a realização da Segunda Convenção da Cruz Vermelha de Genebra de 1906. Assim, a Segunda Conferência de Paz da Haia foi adiada para 15 de julho de 1907.

\subsection{O Contexto Histórico Brasileiro}

No continente americano, ao contrário do restante do planeta, não havia disputa entre potências por áreas de influência. Isso não significa, todavia, que não houvesse imperialismo. No Novo Mundo, os Estados Unidos eram a única potência. Washington pretendia, no início do século $\mathrm{XX}$, reavivar a Doutrina Monroe, conhecida pela célebre frase: "a América para os americanos". Sob o argumento de defender o hemisfério ocidental da ingerência de potências europeias, nos primeiros anos de independência da maioria dos países latino-americanos, a doutrina era na verdade um instrumento do imperialismo norte-americano, que buscava assegurar influência exclusiva sobre os países das Américas.

Expressa pela primeira vez em 1823, pelo Presidente James Monroe, dos Estados Unidos, a doutrina hostilizava as tentativas de colonização ou intervenção europeias no continente americano, principalmente no que se refere à integridade territorial. Mais tarde, foi reafirmada pelo Presidente Theodore Roosevelt, que ao conciliar monroísmo com intervencionismo, fundou o conhecido Corolário Roosevelt à Doutrina Monroe. O corolário confirmou o papel auto-atribuído dos Estados Unidos como nação 
responsável por assegurar a ordem e a paz na América, atuando de fato como a grande potência do Novo Mundo ${ }^{29}$.

Os Estados Unidos haviam alcançado o posto de potência mundial por volta dos primeiros anos do século $\mathrm{XX}^{30}$. O Barão do Rio Branco, Ministro das Relações Exteriores do Brasil de 1902 a 1912 e patrono da diplomacia brasileira, estava consciente da influência norte-americana no novo plano mundial, desta forma procurava aproximar-se dos Estados Unidos sem abrir mão da autonomia de ação do Brasil no plano mundial ${ }^{31}$. Essa política de aproximação a Washington foi definida pelo historiador norte-americano Bradford Burns como uma "aliança não-escrita" ("unwritten aliance") ${ }^{32}$, e

29 "O conceito de proteção do hemisfério contra agressões extracontinentais, cerne daquela doutrina, foi retrabalhado pelo então Presidente norte-americano, de forma que desse justificativa à política de coerção contra os Estados latino-americanos. Como contrapartida, os Estados Unidos garantiram à Europa que as nações latinas da América, sob sua supervisão, preservariam a ordem pública e manteriam seus compromissos em dia." BUENO, Clodoaldo. CERVO, Amado Luiz. História da política exterior do Brasil. 3 ed. Brasília: Ed. UnB, 2008. Pp 180, 181.

30 "Nesse sentido, o próprio Barão do Rio Branco afirmava: "Mais fundamentos teriam para se molestar com as declarações da mensagem [de Roosevelt] essas grandes potências europeias pelo propósito que o governo dos Estados Unidos mostra de intervir, sempre que for necessário, na questão do oriente europeu e nas da Ásia, que as mesmas entendiam pertencer-lhes exclusivamente. A verdade é que só havia grandes potências na Europa e hoje elas são as primeiras a reconhecer que há no Novo Mundo uma grande e poderosa nação com que devem contar e que necessariamente há de ter a sua parte de influência na política internacional do mundo inteiro." Arquivo Histórico do Itamaraty, Despacho reservado para Washington Rio Branco a Gomes Ferreira, 31/01/1905.

31 "Entre 1902 e 1912, a ativa política externa brasileira estava sob o comando do barão do Rio Branco, um homem preocupado com o lugar do país no novo sistema de nações que se delineava. A política internacional então defendida tinha três eixos fundamentais: a aproximação com os Estados Unidos - o maior importador de café e de outros produtos brasileiros, além de potência hemisférica cuja amizade poderia significar benefícios e proteção; a delimitação definitiva das fronteiras e a promoção incansável de uma imagem positiva do Brasil no exterior. No entanto, essa relação mais estreita com os Estados Unidos - útil tanto do ponto de vista da segurança quanto do ponto de vista do progresso material - não deveria ser de subordinação, e sim de respeito recíproco." Christiane Laidler de Souza. Nossa águia em Haia. http://www.revistadehistoria.com.br/secao/artigos/nossa-aguia-em-haia

${ }^{32}$ BURNS, Bradford. The Unwritten Alliance: Rio-Branco and Brazilian-American Relations. New York: Columbia University Press, 1966. 34o p. 
ficou conhecida na história das relações internacionais do Brasil como "política externa americanista pragmática".

A atuação do Brasil na Conferência de 1907 oferece exemplo claro da política americanista pragmática. O Brasil apoiou os Estados Unidos em diversos momentos. Quando valores caros à nação estavam em risco, contudo, o país divergiu firmemente. $\mathrm{O}$ caso da definição da nacionalidade dos juízes a serem indicados para a Corte Permanente de Arbitragem e para o Tribunal de Presas, - que serão aprofundados no próximo capítulo desta monografia -, dão exemplos dessa atitude, conforme pode ser notado no trecho, a seguir, da oração conclusiva de Rui Barbosa na Conferência. Ao referir-se à discordância suscitada entre Brasil e Estados Unidos nos debates em que as grandes potências favoreciam o estabelecimento de condições desiguais de representação dos Estados na Corte Permanente de Justiça Arbitral e no Tribunal de Presas de Guerra, o delegado brasileiro defende o princípio da igualdade como "direito manifesto", e recorda o apoio do Brasil àquele país em todas as outras matérias relevantes:

\footnotetext{
"Por ocasião do projeto que nos separou [dos Estados Unidos], nosso governo não poupou esforços para evitar aquele erro [acusar-se o Brasil de causador de dissensos]. Não nos deram ouvidos, e deste modo nos forçaram ao dissentimento, de que ora nos acusam. Essa divergência, porém, circunscreveu-se aos dois casos em que era de uma necessidade inelutável: o da classificação dos Estados soberanos, que daria em terra com os fundamentos de todo o Direito Internacional, e o do Tribunal de Presas, cuja organização nos despojava, sem motivo, nem pretexto possível, de um direito manifesto. Fora isso, estivemos com os Estados Unidos em todas as suas propostas de
} 
maior monta: a isenção da propriedade particular na guerra naval, a cobrança das dívidas contratuais, o arbitramento obrigatório, a periodicidade das Conferências." 33

Mais adiante em seu último discurso, procura sublinhar os elementos que, a despeito de eventuais diferenças, aproximavam Brasil e Estados Unidos:

"Sempre nos pareceu a nós que, para nos elevarmos à altura de uma nobre amizade, havíamos de começar merecendo-a pela estima de nós mesmos. A mútua independência não arrefece, antes deve estimular e aprofundar a cordialidade entre nações, que timbrando na sua honra, entre si, contraíram, pela sua história e pelos seus interesses, íntimas simpatias e relações necessárias. A justiça recíproca e o laço mais firme cria grandes amizades; e os dois maiores Estados das duas Américas não se poderão esquecer nunca mais do modo como ambos a praticaram um com o outro, o Brasil no arbitramento do Alabama, o mais memorável da história, e os Estados Unidos na sentença arbitral de Cleveland. Acrescentai a excursão de Root, último atestado de solidariedade do hemisfério americano, e tereis de concluir que, embora a América do Norte e a América do Sul possam diversificar as suas opiniões, a alma é a mesma, o mesmo futuro, e nos sentimentos não poderão colidir." ${ }^{34}$

Foi através dessa "aliança não-escrita" que o Brasil tornou-se o primeiro país da América do Sul a estabelecer uma Embaixada nos Estados Unidos (1905), tendo Joaquim Nabuco à sua frente. O contato direto com Washington mostrou-se essencial para o adiamento da Segunda Conferência, como visto anteriormente, bem como para diversas outras gestões ao longo da mesma.

${ }^{33}$ BARBOSA, Rui. Obras Completas de Rui Barbosa. vol. XXXIV, Tomo II. Rio de Janeiro: Ministério da Educação e Cultura, 1966. p. 390. Tradução livre do original em francês, disponível no site:

<http://docvirt.com/docreader.net/docreader.aspx?bib=ObrasRuiMP\&pasta=Vol.\%20XXXIV \%20(1907)\Tomo\%20II\&pesq=\&paglog=>, último acesso em 19 de mar. 2013.

${ }^{34}$ BARBOSA, Rui. Obras Completas de Rui Barbosa. vol. XXXIV, Tomo II. Rio de Janeiro: Ministério da Educação e Cultura, 1966. p. 391. Tradução livre do original em francês, disponível no site:

<http://docvirt.com/docreader.net/docreader.aspx?bib=ObrasRuiMP\&pasta=Vol.\%20XXXIV \%20(1907)\Tomo\%20II\&pesq=\&paglog=>, último acesso em 19 de mar. 2013 
A estratégia americanista fazia parte de um plano maior do Barão do Rio Branco, que procurava reforçar as relações internacionais do Brasil no plano multilateral, restaurando o prestígio internacional do país e defendendo a intangibilidade de sua soberania ${ }^{35}$.

O Brasil ainda tinha questões de fronteira há serem resolvidas e a república formada recentemente precisava solucionar questões internas e firmar a sua posição tanto na América do Sul como no mundo. Em outras palavras, o país precisava atualizar sua agenda internacional urgentemente.

Não é de outra forma que Rui Barbosa via esse cenário, conforme discurso proclamado durante homenagem recebida em Paris, e que deveria, nas palavras de João Neves da Fontoura, estar inscrito "num muro de bronze às portas do Itamarati" ${ }^{36}$ :

"Hoje mais do que nunca, a vida - assim moral como econômica das nações - é cada vez mais internacional. Mais do que nunca, em nossos dias os povos subsistem da sua reputação no exterior. Sobretudo os povos em elaboração como o nosso, como todos os do nosso continente. As correntes, de que se vê atualmente sulcada em todos os sentidos a superfície do globo, já não permitem as civilizações isoladas, nacionais, de

\footnotetext{
35 "A trajetória da diplomacia brasileira na primeira metade do século XX é marcada por uma série de desafios característicos de uma nação ainda em formação, como a definição de fronteiras territoriais e o desenvolvimento social, político e econômico. O Brasil buscava, assim, a consolidação de sua indentidade nacional, em um processo que lançou as bases clássicas desta mesma diplomacia, sustentada no pacifismo, no não confrontacionismo, na defesa da soberania e igualdade entre as nações, na não ingerência e na tradição jurídica de respeito às normas internacionais. Estas questões de fortalecimento interno tinham igualmente uma contrapartida externa, na qual surgiam como demandas o estabelecimento do Brasil na América do Sul e em âmbito mundial. Neste campo, a busca de uma política externa própria e autônoma passava não só por esta dimensão doméstica que definiria a base de poder a partir da qual o país se projetaria no sistema internacional, mas pelas pressões deste mesmo cenário." VISENTINI, Paulo Fagundes. "A Águia de Haia": Rui Barbosa Diplomata. In: NAGLE, Marilene; WIESEBRON, Marianne L. (Orgs.). Rui Barbosa: uma personalidade multifacetada. Brasília: FUNAG, 2012. p. 49.

${ }^{36}$ BARBOSA, Rui. A Conferência de Haia: dois autógrafos do arquivo da Casa de Rui Barbosa. Rio de Janeiro: Casa de Rui Barbosa, 1952. p.11
} 
outros tempos. As mais confinadas de outrora, as do remoto e misterioso oriente, essas mesmas não resistem à invasão, e até lhe abrem os braços. Quanto mais nós, que temos na Europa a nossa ascendência direta e dela haurimos dia a dia na sua cultura, na sua emigração, nos seus capitais, a substância do nosso crescimento. Quando os nossos estadistas se convencerem de que no exterior do Brasil, na sua boa nomeada entre as nações está o mais seguro critério dos seus interesses, a influência dessa preocupação terá sobre o nosso desenvolvimento efeitos incomparáveis. Ela nos temperará as paixões, nos abonançará as lutas, nos civilizará os costumes, nos facilitará os problemas, dará outro tom, outra direção, outro movimento, outra energia, outra fecundidade às nossas instituições, às nossas aspirações, às nossas deliberações. Será para a nossa política uma era nova, determinada pelo nosso contacto, pela nossa cooperação, pela nossa intimidade, com as grandes nações de um e outro hemisfério, das quais nos aproximaremos no valor, aproximando-nos nas relações." ${ }^{37}$

A primeira prova dessa nova perspectiva das relações internacionais brasileiras teve lugar na Segunda Conferência de Paz da Haia de 1907. Pela primeira vez, o Brasil participava de um encontro mundial, sentando-se lado a lado com as grandes potências ${ }^{38}$.

A ideia de convidar todas as nações latino-americanas ${ }^{39}$, inclusive aquelas que não haviam sido convidadas para a Primeira Conferência, partiu do Secretário de Estado norte-americano John Hay, e foi apoiada pelo seu sucessor, Elihu Root ${ }^{40}$. Cabe lembrar que, para a Conferência de

${ }^{37}$ BARBOSA, Ruy e ALMEIDA, Gabriel de Toledo Piza. Manifestação dos brasileiros de Paris em honra do Exmo. Sr. Ruy Barbosa, Embaixador do Brasil em Haya. Paris: Alcan-Lévy, 1907. $31 \mathrm{p}$.

38 “A participação do Brasil na Conferência da Haia representava simbolicamente o ingresso do País na cena internacional. Era o primeiro encontro verdadeiramente universal com a presença do Brasil. Até então, a experiência multilateral brasileira se restringia às conferências panamericanas." AMORIM, Celso. A diplomacia multilateral do Brasil: um tributo a Rui Barbosa. Brasília: Fundação Alexandre de Gusmão, 2007. 6 p.

39 Os países latino-americanos representados na Conferência de Paz de 1907 foram: Argentina, Bolívia, Brasil, Chile, Colômbia, Cuba, República Dominicana, Equador, Guatemala, Haiti, México, Nicarágua, Panamá, Paraguai, Peru, El Salvador, Uruguai e Venezuela.

40 "Hay trouxe a idéia de convidar todas as nações latino-americanas, que, não convidadas para a I Conferência, estavam mais atentas às próprias posições no mundo e desejavam participar da política internacional em escala global. Isso estava em consonância com os anseios do Barão do Rio Branco, já Ministro das Relações Exteriores, de expandir a participação brasileira nos 
1899 apenas Brasil e México haviam sido convidados na América Latina. Como o Brasil não pode enviar delegação naquela ocasião, por dificuldades internas $^{41}$, apenas o México compareceu.

A participação brasileira na Segunda Conferência foi resultado de uma das mais bem sucedidas parcerias da política externa brasileira, entre o Barão do Rio Branco e Rui Barbosa. Ela estabeleceu princípios norteadores para as relações internacionais do país, como o comprometimento com a resolução pacífica das controvérsias; a coordenação política na América do Sul; a defesa intransigível do Direito Internacional, do pacifismo, da não ingerência, da soberania e da igualdade entre os Estados - princípios que ainda são seguidos pelo Brasil no presente ${ }^{42}$.

processos de concertação internacional. Elihu Root, que assumiu o Departamento de Estado em 1905, persuadiu as nações europeias a convidarem todas as nações ocidentais, dando continuidade aos esforços de seu antecessor." MUNIZ, Adam Jayme. Águia na Haia: olhar geral sobre a participação brasileira na II Conferência de Paz. Juca: A revista dos alunos do Instituto Rio Branco. Brasília, no 01, 2007. p. 16.

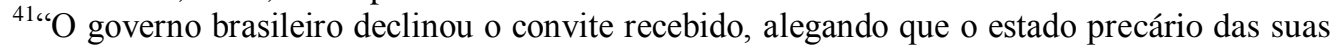
forças armadas, devido às crises por que têm passado, nestes últimos anos, o Brasil, não lhe permitia "tomar de antemão compromisso algum para a manutenção do statu quo militar"." MELLO, Rubens Ferreira de. Dicionário de Direito Internacional Público. Rio de Janeiro: Instituto Rio Branco, 1962. p. 289

42 “Contemporâneo do Barão do Rio Branco, o patrono da nossa diplomacia, Rui inaugurou uma linha de atuação que perdura até hoje: a defesa da igualdade entre os Estados e da democratização das relações internacionais." AMORIM, Celso. A diplomacia multilateral do Brasil: um tributo a Rui Barbosa. Brasília: Fundação Alexandre de Gusmão, 2007. p.5 
PARTE II - RUI BARBOSA E A CONFERÊNCIA DA HAIA DE 1907 


\section{CAPÍTULO 3 - A ÁGUIA DA HAIA}

A participação de Rui Barbosa na Conferência de Paz da Haia de 1907 representou momento decisivo na defesa dos direitos dos países mais fracos. O delegado brasileiro levantou-se contra os projetos de criação de um Tribunal de Presas de Guerra e de uma Corte Permanente de Justiça Arbitral, que reservavam a juízes das grandes potências notória primazia, instituindo uma "justiça dos fortes". Evitou, assim, que o Brasil e outros países, no início de sua atuação multilateral, fossem colocados em posição inferior.

Ao voltar ao Brasil, após mais de quatro meses na Europa, o jurista foi recebido no Palácio do Catete pelo Presidente Afonso Pena, aclamado pela população. Os jornais brasileiros disseminaram a alcunha de “Águia da Haia", consagrando-o como um grande diplomata brasileiro ${ }^{43}$.

43 "Tenho prazer em mandar-lhe a retificação do Independent. V. pode estar certo de que seu nome ficará ligado à tradição da Haia. O ministro da Dinamarca dizia-me uma vez: "C'était très intéressant d'entendre M. Rui Barbosa." O Encarregado da Holanda disse ao Amaral que na Conferência houve três homens: V., o Barão von (sic) Marschall [Marschall von Bieberstein, delegado plenipotenciário da Alemanha em Haia.] e o Bourgeois [Léon Bourgeois, primeirodelegado plenipotenciário da França em Haia.]." Carta de Joaquim Nabuco a Rui Barbosa, 11/04/1908 apud ALENCAR, José Almino de; SANTOS, Ana Maria Pessoa dos. Meu caro Rui, meu caro Nabuco. Rio de Janeiro: Casa de Rui Barbosa, 1999. p. 77.

Igualmente, a Tribune, de Londres, editorializava a 11 de outubro que: "No princípio o barão Marschall von Bieberstein era o homem da conferência. Mas a sua estrela declinou, enquanto a de Mr. Barbosa atingia o meridiano." Apud AMARAL, Márcio Tavares d’. Rui Barbosa. São Paulo : Ed. Três, 2003. p. 195. 


\subsection{A Escolha do Delegado do Brasil para a Conferência de Paz da Haia de 1907}

O Barão do Rio Branco escolheu primeiramente Joaquim Nabuco para chefiar a delegação brasileira à Conferência de 1907, decisão que teve por base a atuação de Nabuco na Conferência Pan-Americana do ano anterior no Rio de Janeiro, e sua boa relação com os Estados Unidos, onde era o Embaixador do Brasil desde 1905. O Correio da Manhã, influente jornal de oposição, reagiu, dando início a uma campanha em favor do nome de Rui Barbosa, então vice-presidente do Senado. A primeira página do jornal, em sua edição de 14 de janeiro de 1907, fazia duras críticas a Nabuco. A campanha surtiu efeito, sendo apoiada por outros jornais e por parte expressiva da opinião pública ${ }^{44}$.

Levando em conta a capacidade intelectual de Rui Barbosa e os temas jurídicos da conferência, o Barão imediatamente aceita a sugestão de indicar o vice-presidente do Senado. Mantém, no entanto, o convite feito a Nabuco. A ideia de Rio Branco, comprovada por telegrama enviado a Nabuco, era que os dois repartissem a delegação: "Já houve ministério águias, poderíamos ter ali delegação águias, se você quisesse." 45

\footnotetext{
${ }^{44}$ Igualmente, os Senadores Antônio Azeredo e Pinheiro Machado defendem o nome de Rui Barbosa como representante do Brasil na Haia. O diplomata e historiador Manuel de Oliveira Lima, articulista do Correio da Manhã, também ressalta, em seu livro Pan-americanismo (1907), o nome do vice-presidente do Senado. Ele defende que a escolha do delegado deve ser feita pelo critério da intelectualidade, sendo pouco relevante a experiência diplomática.

${ }^{45}$ LINS, Álvaro. Rio-Branco (O Barão do Rio-Branco): biografia pessoal e história política. 2. ed. São Paulo : Cia. Ed. Nacional, 1965. p. 373.
} 
Apesar de serem os dois candidatos amigos de longa data, - Rui conhecera Nabuco ainda estudante, na faculdade de direito de São Paulo, em 1868 -, a proposta de repartição da delegação mostra-se impraticável ${ }^{46}$, conforme o próprio Nabuco explica ao colega escritor e diplomata José Pereira da Graça Aranha, em carta de 4 de março de 1907:

"O Rio Branco quer mandar-me à Haia com Rui e por mais que eu deseje dar ao Rui essa prova de amizade e de confiança, por mais que me custe não estar com ele na Europa e estreitar as relações de tantos anos interrompidas pelas Revoluções, gozar, em uma palavra, da intimidade dele em condições que tornam a intimidade mais íntima, o Sr. sabe bem pela nossa experiência em comum, eu não posso ir à Haia como segundo e ele só pode ir como primeiro. O Rio Branco quer fazer as coisas a seu modo, e impor por meio de habilidades diplomáticas as suas invenções, o seu protocolo, acha que eu posso ir como segundo, que só sou Embaixador aqui... O defeito do Rio Branco é não poder julgar o caso dos outros como se fosse o próprio." ${ }^{, 7}$

Graça Aranha, analisando os motivos de Rio Branco, responde a Nabuco:

“A que móvel obedeceu esse convite? É um dos enigmas da esfinge. O Hilário pensa que foi obedecendo a uma sugestão do Correio da Manhã. Mas o Rui está brigado com o Correio. Talvez fosse para conquistar um adversário, o que é a eterna mania do Rio Branco, a cuja iniciativa se deve isso" 48

Rui Barbosa já se envolvera, em passado recente, em controvérsia com Rio Branco. Expressara publicamente sua oposição ao Tratado de Petrópolis, de 1903, pelo qual o Brasil incorporou o território do atual Estado do Acre, mediante pagamento de indenizações à Bolívia e o

${ }^{46} \mathrm{O}$ duplo convite também desgostava a José Carlos Rodrigues, dono do Jornal do Comércio, e Hilário de Gouveia, cunhado de Joaquim Nabuco.

${ }^{47}$ Carta de Washington, 4 de março de 1907. Coleção Múcio Leão. Apud FIHO, Luiz Viana. A vida do Barão do Rio Branco. Rio de Janeiro : J. Olympio, 1959. p. 380.

${ }^{48}$ FIHO, Luiz Viana. A vida do Barão do Rio Branco. Rio de Janeiro : J. Olympio, 1959. p. 380. 
compromisso de construir a ferrovia Madeira-Mamoré. Rui, que havia sido convidado por Rio Branco para estudar a questão com a Bolívia antes da celebração do Tratado, preferia que o Brasil buscasse o arbitramento dos Estados Unidos para solucionar o problema.

Aquele episódio foi recordado em 1907 por José Joaquim Seabra, exMinistro das Relações Exteriores, em periódico da época. Nessa situação, Rui Barbosa chega a recusar o convite, justificando-se pela complexidade da matéria da Conferência. Rio Branco, porém, insiste e escreve-lhe em 24 de março de 1907: "A nossa divergência pertence ao passado e durante ela, respeitando sempre as convicções alheias, procurei proceder de modo a não perder a estima e a amizade de V. Exa. Que tanto prezo."49

Em $1^{\circ}$ de abril de 1907, Rui Barbosa aceita finalmente a indicação ${ }^{50}$ e no dia seguinte telegrafa a Nabuco: "Aceitei Haia contando sua companhia. Abraços. Rui"51. O outro responde: "Saúde obriga-me declinar, mas estarei

49 Arquivo da Casa de Rui Barbosa Apud LINS, Álvaro. Rio-Branco (O Barão do RioBranco): biografia pessoal e história política. 2. ed. São Paulo : Cia. Ed. Nacional, 1965. p. 374.

${ }^{50}$ Explicando os motivos da concordância, Rui Barbosa diz: "O nosso preclaro chanceler teve que tornar à minha casa mais de uma vez, instando por uma decisão favorável, a que não cheguei senão com quarenta e dois dias de repugnâncias e receios. Isto presenciou, continuadamente entre muitos outros, o Sr. Antônio Azeredo, cuja exma. Senhora foi quem, escrita a carta de resposta, ma obteve, e tomou das mãos, quando eu, ainda então vacilava em ceder. Lembro-me que era um domingo, e que, ao entregar eu o documento do meu compromisso, no mesmo ponto, como apostada, uma banda, que tocava ali perto, no pavilhão do largo, encetou a música dolorosa da Tosca, na ocasião em que se aproxima o desenlace trágico da partitura, e que essa coincidência, notada por mim aos circunstantes, despertou no meu espírito, assustado com a hipótese de um desastre na empreitada cuja responsabilidade acabava de assumir, impressões supersticiosas."

${ }^{51}$ ALENCAR, José Almino de; SANTOS, Ana Maria Pessoa dos. Meu caro Rui, meu caro Nabuco. Rio de Janeiro: Casa de Rui Barbosa, 1999. p. 47. 
em pensamento seu lado, orgulhoso ver Brasil assim representado entre nações. Muitos muitos parabéns. Nabuco.",52

Do conturbado processo de escolha do representante do Brasil não sobraram ressentimentos. O resultado foi a união de três dos maiores intelectuais da época, que colocaram o interesse público como prioridade em suas relações ${ }^{53}$.

O Barão enviou a Rui Barbosa uma série de documentos sobre o programa da Conferência e organizou a recepção do Senador na Europa. Rio Branco queria que o representante brasileiro tivesse uma posição honrosa na Conferência. Dessa forma, instrui o Embaixador em Washington, Joaquim Nabuco, a promover na capital norte-americana a nomeação de Rui Barbosa como chefe da delegação brasileira à Haia. A soma desses esforços resulta na eleição do delegado brasileiro como presidente de honra da Primeira Comissão, das quatro que integrariam a Conferência, aquela responsável pela solução pacífica de conflitos internacionais e pela organização do Tribunal de Presas.

Nabuco, por sua vez, enviou a Rui Barbosa notas confidenciais que continham minuciosas informações sobre cada representante das potências

\footnotetext{
52 ALENCAR, José Almino de; SANTOS, Ana Maria Pessoa dos. Meu caro Rui, meu caro Nabuco. Rio de Janeiro: Casa de Rui Barbosa, 1999. p.48.

53 "As três personalidades políticas consideradas as mais afirmativas e as mais brilhantes da época estavam agora colocadas num mesmo terreno, e cada uma delas desempenhou o seu papel de modo admirável. Nenhum sentimento de inveja, nenhum impulso mesquinho." LINS, Álvaro. Rio-Branco (O Barão do Rio-Branco): biografia pessoal e história política. 2. ed. São Paulo : Cia. Ed. Nacional, 1965. p. 373.
} 
participantes da conferência. Além disso, o diplomata viajou pela Europa para preparar a recepção de Rui.

Em 1/5, decreto do Presidente Afonso Pena nomeia Rui Barbosa Embaixador Extraordinário e Plenipotenciário do Brasil e Chefe da Delegação à Haia. A delegação foi integrada por diversos diplomatas, incluindo o Ministro Plenipotenciário da Legação do Brasil junto à Corte da Holanda, Eduardo dos Santos Lisboa, além de dois oficiais das forças armadas. No dia 22 de maio, Rui Barbosa, sua esposa, Maria Augusta, duas de suas filhas e o restante da comitiva ${ }^{54}$ embarcam no navio Araguaia para a Europa. A bordo do Araguaia, estava também o delegado e ex-Chanceler argentino, Luís María Drago, que se notabilizara pela "Doutrina Drago". Esta defendia a soberania de nações devedoras diante de potências credoras $^{55}$. Rui Barbosa imediatamente tornou-se amigo de Drago, fato que o ajudaria ao longo da Conferência.

\subsection{A Conferência de Paz da Haia de 1907}

\footnotetext{
54 “a Delegação, escolhida com miudeza, que partiu para Haia em maio de 1907 era composta por Rui Barbosa, "Embaixador Extraordinário e Plenipotenciário e Delegado Plenipotenciário", por Eduardo dos Santos Lisboa, "Ministro Plenipotenciário e Delegado", por dois delegados técnicos, por três Primeiros Secretários e cinco Segundos Secretários. Era uma das maiores delegações da Conferência, a maior dentre os latino-americanos, maior até que a delegação dos Estados Unidos" MUNIZ, Adam Jayme. Águia na Haia: olhar geral sobre a participação brasileira na II Conferência de Paz. Juca: A revista dos alunos do Instituto Rio Branco. Brasília, nº 01, 2007. p.18

${ }^{55}$ A Doutrina Drago, formulada pelo então Chanceler da Argentina em fins de 1902, surgiu como reação ao bloqueio e bombardeio de La Guayra, Puerto Cabello e Maracibo por forças navais do Reino Unido, Alemanha e Itália, que buscavam exigir da Venezuela o pagamento de dívidas externas. Surgiu como protesto contra os Estados Unidos, que naquela ocasião não ofereceram apoio à Venezuela, contrariando a solidariedade pan-americana e a própria Doutrina Monroe.
} 
É comum encontrar na historiografia do século XX referências negativas à Segunda Conferência de Paz da Haia. O fato de não ter permitido alcançar compromisso referente a limitação da corrida armamentista e de não haver impedido a deflagração da Primeira Guerra Mundial são sempre recordados. É preciso, contudo, avaliar a importância da conferência não pelo que logrou concluir, mas pelo que conseguiu iniciar. A Segunda Conferência aprovou um total de treze Convenções, enquanto a primeira, em 1899, apenas aprovara quatro. Esse conjunto de Convenções são ainda hoje marco essencial para duas importantes áreas do Direito Internacional: i) a codificação do direito internacional humanitário, também chamado Direito da Guerra ou Direito dos Conflitos Armados; e ii) o estabelecimento de mecanismos e parâmetros de solução pacífica de disputas.

A Conferencia da paz de 1907, como aquela que a precedeu em 1899, tinha o objetivo declarado de elaborar normas internacionais com o fim de limitar os efeitos dos conflitos armados, além de aprimorar os mecanismos de solução pacífica de controvérsias para evitá-las, em especial as regras de arbitragem. Em 1907, foi revisada a Convenção sobre Solução Pacífica de Controvérsias- mediante a qual a Primeira Conferência criara a Corte Permanente de Arbitragem. Foram também aprimoradas as regras de procedimentos arbitrais.

Os objetivos da Segunda Conferência, contudo, eram ainda mais ambiciosos. Algumas nações estavam dispostas a negociar regras para limitação de armamentos e do uso da força. Além disso, estava em pauta a criação das duas primeiras cortes com jurisdição mundial: um Tribunal de Presas de Guerra e um Tribunal Permanente de Justiça Arbitral. Embora esses tribunais não tenham sido efetivamente criados, como se verá adiante, 
foram objetos, respectivamente, de uma Convenção e de uma Declaração adotadas pela conferência.

No dia 15 de junho de 1907, no palácio Binnenhof, foi aberta a Segunda Conferência de Paz da Haia. Todos os delegados entraram juntos na grande "Sala dos Cavaleiros" ("Ridderzaal") e sentaram-se em enorme mesa oval, de modo que nenhum país fosse considerado superior aos demais. Como a Rússia havia convocado a Conferência, Alexandre Ivanovitch Nelidov, chefe da delegação russa, foi o presidente da assembleia e declarou iniciados os trabalhos.

No dia 19 de junho ficou estabelecida a divisão da Conferência em quatro comissões: Primeira - solução pacífica de conflitos internacionais e organização do Tribunal de Presas; Segunda - melhoria das leis e costumes da guerra terrestre e do direito e obrigações dos neutros em terra; Terceira questões de portos: bombardeio de portos, colocação de minas submarinas e torpedos, condição dos navios beligerantes em portos neutros; Quarta principais temas relativos à guerra marítima.

As primeiras sessões eram meramente formais. Talvez porque estivesse consciente de não possuir a experiência diplomática necessária, rui Barbosa esforçou-se em demasia nos aspectos meramente formais, enquanto os delegados de outros países faziam alianças e acumulavam forças. Era intenção de Rui participar pessoalmente de todas as comissões, mas, devido aos horários coincidentes, decide-se pela Primeira, que presidia, e pela Quarta. 
As primeiras participações de Rui Barbosa revelam coincidência de posições com os Estados Unidos ${ }^{56}$. Em seu primeiro grande discurso, em 28 de junho de 1907, perante a Quarta Comissão, Rui, ao lado dos norteamericanos, defende que a propriedade particular dos súditos ou cidadãos de uma das potências beligerantes no alto mar não poderia ser apreendida por navios de guerra de outra potência, salvo no caso de contrabando de guerra. O Brasil já havia adotado essa imunidade da propriedade privada no mar ao celebrar em 1828 o Tratado de Paz, Amizade, Navegação e Comércio com os Estados Unidos.

\subsubsection{O Incidente Martens}

O trabalho incansável de Rui Barbosa, que discursava e oferecia pareceres sobre quase todas as questões, gerou certa antipatia nos delegados das grandes potências, que esperavam encontrar países sul-americanos dóceis e humildes ${ }^{57}$.

${ }^{56}$ Os primeiros dias de Rui na Haia foram dificeis: "a primeira impressão entre os hispanoamericanos, ao chegar o Dr. Barbosa a Haia, era que o delegado do Brasil faria o papel de SextaFeira ao lado de Robinson Crusoe [que seria os Estados Unidos]" STEAD, William. O Brasil em Haia. trad. em português, Rio de Janeiro, 1909. p.25.

${ }^{57}$ Comenta, Rui Barbosa: "Nem....angariamos, na primeira fase da conferência, a boa sombra da Europa. Ali não se levava muito a bem a liberdade, assumida por um governo remoto, desconhecido e inerme, de interpor com isenção o seu juízo nas principais questões oferecidas pelo direito das gentes aos debates daquela assembleia." BARBOSA, Rui. Obras Completas de Rui Barbosa. vol. XXXIV, Tomo II. Rio de Janeiro: Ministério da Educação e Cultura, 1966. p. 13. Disponível no site:

$<$ http://docvirt.com/docreader.net/docreader.aspx?bib=ObrasRuiMP\&pasta=Vol.\%20XXXIV\%20( 1907)\Tomo\%20II\&pesq=\&paglog=>, último acesso em 19 de mar. 2013.

No mesmo sentido, narra, Baptista Pereira: "A posição do Brasil era difícil. A hostilidade do ambiente contra o seu embaixador indissimulável. Principalmente de grande parte dos latinoamericanos. Muitos destes, quando Rui começava a falar, abriam ostensivamente os jornais. William Stead mudara-lhe o nome para Dr. Verbosa. Queriam emudecê-lo. O ceticismo dominava. A consciência jurídica era importuna. Urgia conciliar os interesses de uma forma que desse ao 
No dia 12 de julho, a quarta comissão discutia a questão da transformação dos navios mercantes em vasos de guerra. Rui Barbosa, em minucioso discurso, defendeu que a Conferência de Paz de 1907 deveria ser um Parlamento das Nações e dos Povos, e que, para isso, era preciso privilegiar os debates e a política. O delegado brasileiro ressaltou de forma pioneira a importância da democratização das relações internacionais. Pela primeira vez, defendia-se, no campo externo, o modelo interno da democracia liberal:

"Nós demos a essa Conferência o nome de parlamento das nações. Ora, é da essência dos parlamentos o falarem, isto é, que eles não se limitem a votar, mas que eles discutam com a mais ampla liberdade de palavra. A palavra não é nociva, mesmo quando ela transborda. E a esse propósito, permitam-me não aquiescer à frase espiritual de um ilustre membro dessa assembleia, segundo a qual quanto mais nós discutimos aqui, mais nós divergimos. É justamente o contrário que, a meu ver, atesta a evidência dos fatos. Se não houvéssemos discutido certos assuntos com alguma largueza de apreciação em nossas comissões plenas, não teríamos podido chegar às comissões de exame. É nos países onde se desconfia da palavra e onde ela é proscrita que não se chega jamais a um acordo e os antagonismos são irredutíveis. Nos países onde incessantemente se agita a discussão, como na Inglaterra e nos Estados Unidos, sempre se chega ao acordo e não existem problemas insolúveis.. ${ }^{58}$

O Presidente da Quarta Comissão e chefe da delegação russa, Fyodor Martens, demonstrando antipatia ao delegado brasileiro, declarou que o discurso do Brasil seria impresso e inserido na ata dos trabalhos. Lembrou que a política deveria ser excluída das deliberações da Comissão, uma vez

mundo a ilusão de que se tinha feito alguma coisa de útil; mas era preciso pedir o santo e a senha às grandes potências.” PEREIRA, Antonio Baptista. Ruy na Conferência de Haya, in Figuras do Império e outros ensaios. Brasília: Senado Federal, 1991.

${ }^{58}$ BARBOSA, Rui. Obras Completas de Rui Barbosa. vol. XXXIV, Tomo II. Rio de Janeiro: Ministério da Educação e Cultura, 1966. pp. 54, 55. Tradução livre do original em francês, disponível no site:

<http://docvirt.com/docreader.net/docreader.aspx?bib=ObrasRuiMP\&pasta=Vol.\%20XXXIV \%20(1907)|Tomo\%20II\&pesq=\&paglog=>, último acesso em 19 de mar. 2013. 
que não seria da alçada da Conferência ${ }^{59}$. Esse pronunciamento do Presidente foi seguido por aplausos de toda a Assembleia, demonstrando a impaciência, a quase hostilidade com que o delegado brasileiro era tratado. Parecia ser a decapitação do Brasil na Haia, o fim do Parlamento das Nações e dos ideais democráticos.

Essa censura a seu discurso fez que Rui pedisse a palavra para tentar mostrar, em francês fluente, embora falando de improviso, que tudo que a Conferência debatia nada mais era que política. De forma elegante, polida, sem erros, Rui diferenciou a política militante, que gera desunião, da política entendida como ciência.

"As palavras com que acabais de receber o meu discurso parece envolverem uma censura, que eu não posso, que eu não devo deixar sem uma resposta imediata, já que essa espécie de censura, se existe de fato, eu não a mereço.

[...] Nós não nos esquecemos que Sua Majestade o Imperador da Rússia, no seu ato convocatório da Conferência de Paz, afastou formalmente do nosso programa as questões políticas. Mas essa interdição, obviamente, só visara a política militante, a política de ação e de combate, essa que tumultua, que agita, que separa os povos nas suas relações internas e nas suas relações internacionais, jamais a política vista como ciência, a política estudada como história, a política explorada como regra moral.

[...] Nós queremos fugir aqui da política? Mas, meu Deus, é pagarmo-nos de nomes e não ver a realidade. A política é a atmosfera dos Estados. A política é a região do direito internacional. De onde é que ele emana se não é da política? São as revoluções, são as guerras, são os tratados de paz que elaboram lentamente esse grande corpo do Direito das Nações.

59 “M. le Président déclare que ce discours sera imprimé et inséré dans le procès-verbal. Il rappelle à ce propos que la politique doit être exclue des délibérations de la Commission; ele n'est pas comprise dans le programme russe, que les puissances ont aprouve, et la circulaire du gouvernemant russe declare formellement que la politique n'est pas du ressort de la Conférence." BARBOSA, Rui. Obras Completas de Rui Barbosa. vol. XXXIV, Tomo II. Rio de Janeiro: Ministério da Educação e Cultura, 1966. p. 60. Disponível no site:

$<$ http://docvirt.com/docreader.net/docreader.aspx?bib=ObrasRuiMP\&pasta=Vol.\%20XXXIV\%20( 1907)\Tomo\%20II\&pesq=\&paglog=>, último acesso em 19 de mar. 2013. 
[...] Aí está por que me encontro obrigado a concluir, por fim de contas, senhores, que, cortarmos o contato com a política de forma total, seria ditar-nos o impossível e seria impedir o próprio uso da palavra." ${ }^{60}$

O discurso não foi seguido por palmas e Martens logo encerrou a sessão, visivelmente desapontado e sem mencionar o incidente. Na sala do "buffet", para onde os delegados se dirigiram após a sessão, Martens procura Rui, pedindo-lhe que não guardasse ressentimentos, abraçando-o. Através da palavra, o Brasil havia angariado o respeito das grandes potências.

Rapidamente, todos na Conferência reconheceram a figura de Rui Barbosa e perceberam que o Brasil não seria apenas mais uma voz ecoando a potência estadunidense. Todos passaram a escutar seus discursos atentamente $^{61}$.

\subsubsection{A Doutrina Drago e a Convenção Porter}

Durante os debates da Primeira Comissão sobre a questão da cobrança das dívidas externas dos Estados, Rui Barbosa foi solidário com os Estados Unidos e, ao menos em parte, contrário à Doutrina Drago.

${ }^{60}$ BARBOSA, Rui. Obras Completas de Rui Barbosa. vol. XXXIV, Tomo II. Rio de Janeiro: Ministério da Educação e Cultura, 1966. pp. 60, 62, 64, 65. Tradução livre do original em francês, disponível no site:

<http://docvirt.com/docreader.net/docreader.aspx?bib=ObrasRuiMP\&pasta=Vol.\%20XXXIV \%20(1907)\Tomo\%20II\&pesq=\&paglog=>, último acesso em 19 de mar. 2013.

61 "Ninguém resumiu melhor do que Brown Scott a filosofia desse incidente: "Voici le nouveau monde qui se fait entendre du viueux".

Há dias conversávamos longamente no Hotel Glória. Hoje, vinte anos depois, como outrora, a sua impressão é a mesma: o incidente De Martens marca a entrada dos povos do futuro nos conselhos da humanidade, foi ele que permitiu à Europa descobrir de novo a América." CARDIM, Carlos Henrique. A Raiz das Coisas: Rui Barbosa: O Brasil no Mundo. Rio de Janeiro: Civilização Brasileira, 2008. p. 195. 
Em seu discurso, demostrou que as dívidas nacionais não são atos de soberania do Estado, e que, dessa forma, podem ser cobradas coercitivamente. Isso não significava, contudo, que Rui fosse favorável ao uso da força para a cobrança de dívidas. Brasil e Estados Unidos apoiaram a adoção da Convenção Porter sobre os Limites do Uso da Força para Recuperação de Débitos Contratados. A Convenção, que ficou conhecida pelo nome de um dos delegados norte-americanos à Conferência, o General e Embaixador Horace Porter, estabelecia o arbitramento como primeiro recurso obrigatório nas controvérsias relativas a dívidas soberanas. A Convenção dispõe que a cobrança por meios coercitivos só poderia ser considerada aceitável após malograda tentativa de solução $\operatorname{arbitral}^{62}$. Rui Barbosa enfatizou que acima do direito de soberania estava a ordem jurídica, o Direito Internacional, que é construído por esses entes soberanos.

Rui também alertou para os riscos que atingiriam os países sulamericanos, caso fossem retirados todos os meios de execução contra os devedores. As ofertas de créditos para os países da América Latina acabariam tornando-se escassas, já que Estados e empresas não ousariam aventurar seu dinheiro sujeitando-o aos riscos do empréstimo.

\footnotetext{
${ }^{62}$ Em seu discurso do dia 23 de julho de 1907: 'C'est fâcheux que l'on se trouve obligé de laisser toujours la guerre au bout de ce que nous faisons pour la paix. Mais tant que la guerre existe et que les hommes tiennet à en faire um moyen de rétablir le droit, on ne saura pas comment empêcher le spectacle mélancolique, auquel forcément nous sommes des acteurs ici-même, de la considérer, pour ainsi dire comme la dernière cour d'appel de ceux qui, en se croyant possesseur d'un droit, ou ayant à leur faveur une décision arbitrale, la voient braver par les rebelles aux voies de la conciliation et aux formes de la justice. Et voici comment il se fait qu'une assemblée réunie pour organiser l'arbitrage et la paix se trouve dans la contingence de reconnaître dans la guerre une espèce d'instance extrême pour les cas d'obstination contre les sentences de l'arbitrage, ou de refus d'accepter son ressort." BARBOSA, Rui. Obras Completas de Rui Barbosa. vol. XXXIV, Tomo II. Rio de Janeiro: Ministério da Educação e Cultura, 1966. p. 94. Disponível no site: <http://docvirt.com/docreader.net/docreader.aspx?bib=ObrasRuiMP\&pasta=Vol.\%20XXXIV\%20( 1907)|Tomo\%20II\&pesq=\&paglog=>, último acesso em 19 de mar. 2013.
} 
Conquanto bem fundamentada, a posição brasileira nessa matéria parece demonstrar disposição em acompanhar- sempre que o interesse do Brasil não fosse comprometido - os Estados Unidos, ainda que, em casos como esse, estivesse em jogo o apoio do Brasil a vizinhos sul-americanos, como a Argentina. É possível que Joaquim Nabuco, Embaixador do Brasil em Washington, e naturalmente propenso a preservar as relações bilaterais com a grande nação do Norte, tenha influenciado a posição negociadora brasileira nesse caso em particular. Outra possibilidade é que Rui houvesse negociado com os Estados Unidos o apoio brasileiro em troca de apoio norte-americano em outros debates da Conferência.

\subsubsection{O Tribunal de Presas}

Os esforços da Conferência para codificação do direito internacional em situações de guerra incluíram debates sobre a criação de um Tribunal de Presas de Guerra, com competência para julgar controvérsias referentes a equipamentos e bens apreendidos por nações inimigas durante guerras, especialmente navios. Nesse contexto, na Primeira Comissão, foi apresentada proposta inglesa de Convenção que estabelecia um tribunal permanente formado por 15 juízes, sendo que as oito maiores potências com marinhas de guerra acima de 800.000 toneladas de deslocamentoindicariam juízes permanentes e os juízes restantes seriam indicados por um complexo sistema de rotação ${ }^{63}$. O tribunal não chegou nunca a ser

63 “O Tribunal seria dividido em dois grupos, um constituído por Alemanha, Áustria-Hungria, Estados Unidos, França, Grã-Bretanha, Itália, Japão e Rússia, cujos juízes exerceriam um mandato permanente. O outro grupo, composto pelos demais países, escalonados em classes, teriam juízes com mandatos variando de quatro anos para juiz e suplente até um ano para suplente apenas." 
estabelecido, pois a convenção acordada em 1907 na Haia não foi ratificada por nenhum dos países signatários. Teria sido, contudo, a primeira verdadeira corte com jurisdição supranacional.

Rui Barbosa, sem contar com o apoio de nenhum dos outros países prejudicados pela proposta inglesa, demonstrou diversas falhas no projeto, entre elas, o fato de não prever a possibilidade de participação dos países cujas marinhas alcançassem, depois da assinatura da Convenção, mais de oitocentas mil toneladas ${ }^{64}$. $\mathrm{O}$ delegado brasileiro considerava que o maior erro do projeto estava na falta de equidade e de justiça no processo de escolha e distribuição de lugares no tribunal.

Os trechos a seguir, de suas intervenções, revelam alguns dos melhores exemplos da defesa do princípio da igualdade no Direito Internacional por Rui Barbosa. Para o delegado brasileiro, é esse o princípio que garantirá que os fracos não sejam submetidos à justiça dos fortes, lembrando ainda que são justamente os fortes que, na sociedade anárquica internacional, têm menos razões para observar a lei:

"Pensai bem, já que não é somente ao comércio dessas marinhas de 800.000 toneladas que nós procuramos dar garantias jurídicas. É um tribunal de jurisdição universal que vamos criar. Todas as marinhas, grandes ou pequenas, dependerão dele.

ALENCAR, José Almino de; SANTOS, Ana Maria Pessoa dos. Meu caro Rui, meu caro Nabuco. Rio de Janeiro: Casa de Rui Barbosa, 1999. 21 p.

64 “Tout d'abord la norme proposée serait incomplète, en tant qu'elle n'a en vue que les marines de plus de 800.000 tonneaux au moment de la signature de la convention, et ne prévoit pas le droit indubitable de celles qui, en se développant, se rangeraient à l'avenir au même étalon." BARBOSA, Rui. Obras Completas de Rui Barbosa. vol. XXXIV, Tomo II. Rio de Janeiro: Ministério da Educação e Cultura, 1966. p. 49. Disponível no site:

<http://docvirt.com/docreader.net/docreader.aspx?bib=ObrasRuiMP\&pasta=Vol.\%20XXXIV \%20(1907)\Tomo\%20II\&pesq=\&paglog=>, último acesso em 19 de mar. 2013. 
Acreditai que elas terão todos os mesmos motivos para confiar nos juízes, para cuja nomeação não contribuíram de forma nenhuma?

Não esqueçais que, sob esse regime, os fracos terão que se submeter à justiça dos fortes. Estes podem ter preocupações comuns que os induzam a não respeitar, suficientemente, certas considerações sobre as quais o direito dos outros depende. São, ordinariamente, os mais fortes que têm menos razões para observar a lei. Como reservar a estes o privilégio da autoridade judiciária?

[...] Além de tudo, as marinhas mercantes que nós excluímos por não ter, individualmente, a tonelada indicada, representam, todavia, em seu conjunto uma tonelagem muito superior à que assegura a cada uma das outras a faculdade de concorrer para a nomeação do tribunal. Por que, pois, excluir da partilha de um tal direito essa massa importante, composta de pequenas marinhas, mas mais majestosa que muitas das grandes?"65

Nas sessões seguintes, Rui demonstra que certos Estados europeus que não possuíam navios teriam um espaço de atuação no tribunal maior do que o espaço reservado ao Brasil e aos demais países da América Latina. O delegado brasileiro provou, por meio de estatísticas insuspeitas ${ }^{66}$, a superioridade do comércio marítimo e até mesmo da marinha de guerra brasileira em comparação a outros países europeus.

Não obstante os esforços de Rui Barbosa, o projeto foi aprovado, recebendo 26 votos favoráveis, 2 contrários (Brasil e Turquia) e 15 abstenções.

${ }^{65}$ BARBOSA, Rui. Obras Completas de Rui Barbosa. vol. XXXIV, Tomo II. Rio de Janeiro: Ministério da Educação e Cultura, 1966. pp. 49, 50. Tradução livre do original em francês, disponível no site:

<http://docvirt.com/docreader.net/docreader.aspx?bib=ObrasRuiMP\&pasta=Vol.\%20XXXIV \%20(1907)|Tomo\%20II\&pesq=\&paglog=>, último acesso em 19 de mar. 2013.

${ }^{66}$ BARBOSA, Rui. Obras Completas de Rui Barbosa. vol. XXXIV, Tomo II. Rio de Janeiro: Ministério da Educação e Cultura, 1966. pp. 210 à 212. Disponível no site:

<http://docvirt.com/docreader.net/docreader.aspx?bib=ObrasRuiMP\&pasta=Vol.\%20XXXIV \%20(1907)|Tomo\%20II\&pesq=\&paglog=>, último acesso em 19 de mar. 2013. 
"Essa iniquidade palpável nos fundamentos de uma instituição judiciária, essa afirmação ostensiva do poder da força contra a razão na obra da mais augusta assembleia do mundo, convocada para organizar a paz mediante o direito, é, infinitamente, dolorosa para as vítimas.

[...] Nosso voto será, portanto, contrário ao projeto. Nós faremos apelo aos tempos onde o espírito dos povos esteja mais maduro para a obra da paz, que não é outra que a do direito mantido sinceramente entre as nações." ${ }^{.67}$

Os argumentos do delegado brasileiro, embora tardiamente, foram reconhecidos, haja vista que a Convenção não foi ratificada por nenhum dos signatários e o Tribunal, nunca foi estabelecido. Muitos países sequer assinaram a Convenção. No dia 26 de outubro, Rússia, Espanha, Grécia, Luxemburgo, Montenegro, Portugal, Romênia, Sérvia, São Domingos e Venezuela abstiveram-se de assiná-la, e até 10 de janeiro de 1908 só 21 das 44 nações presentes à Conferência a firmaram ${ }^{68}$.

\subsubsection{A Corte Permanente de Justiça Arbitral}

A questão central da Segunda Conferência de Paz da Haia foi a criação de uma Corte Permanente de Justiça Arbitral que, apesar do nome semelhante $^{69}$, não extinguiria a Corte Permanente de Arbitragem criada na Conferência de 1899. A proposta norte-americana era criar uma corte

${ }^{67}$ BARBOSA, Rui. Obras Completas de Rui Barbosa. vol. XXXIV, Tomo II. Rio de Janeiro: Ministério da Educação e Cultura, 1966. pp. 316, 317. Tradução livre do original em francês, disponível no site:

$<$ http://docvirt.com/docreader.net/docreader.aspx?bib=ObrasRuiMP\&pasta=Vol.\%20XXXIV \%20(1907)\Tomo\%20II\&pesq=\&paglog=>, último acesso em 19 de mar. 2013.

${ }^{68}$ BARBOSA, Rui. Obras Completas de Rui Barbosa. vol. XXXV, Tomo I. Rio de Janeiro: Ministério da Educação e Cultura, 1967. p. 72. Disponível no site:

$<$ http://docvirt.com/docreader.net/docreader.aspx?bib=ObrasRuiMP\&pasta=Vol.\%20XXXIV\%20( 1907) Tomo\%20II\&pesq=\&paglog >

${ }^{69}$ Ao longo da Segunda Conferência de Paz, ocorreram muitos debates sobre o nome dessa nova Corte. Apesar de receber o nome de uma corte arbitral, seu projeto tinha como base a Suprema Corte dos Estados Unidos. Pode-se dizer que o projeto era criar um "supremo tribunal do mundo". 
mundial para solução jurídica de controvérsias, que manteria sessões regulares e contínuas com juízes permanentes residentes na Haia. $O$ Secretário de Estado dos EUA, Elihu Root, instruíra a delegação de seu país a trabalhar pela criação de um Tribunal Permanente, composto apenas de juízes, sem qualquer outra ocupação que não o julgamento de casos internacionais por métodos estritamente jurídicos. A ela estariam submetidos obrigatoriamente todos os Estados soberanos.

Durante a conferência, o México propôs emenda estabelecendo que as partes em litígio teriam a liberdade de organizar, por meio de acordo mútuo, uma jurisdição especial fora da corte ${ }^{70}$.

Com a intervenção das delegações da Alemanha e da Grã-Bretanha, a proposta dos EUA foi modificada. A Corte seria composta por dezessete juízes, sendo que nove teriam assentos permanentes reservados às oito grandes potências da época mais a Holanda, e os oito restantes seriam indicados por oito grupos de nações. Um desses grupos de nações seria formado pelos países da América do $\mathrm{Sul}^{71}$.

\footnotetext{
${ }^{70}$ Rui Barbosa apoiou a emenda mexicana.

71 "Acabo de ter notícia grave americanos guardam segredo absoluto sobre organização Corte Permanente. Mas por amigo comum tive confidência completa Tribunal terá dezessete membros base população. França, Inglaterra, Alemanha, Áustria, Itália, Rússia, Estados Unidos, Japão, Holanda cada uma um membro. Os mais por grupos seguinte modo: Espanha e Portugal, Bélgica Suíça e Luxemburgo, Turquia e Pérsia, China e Sião, Suécia, Noruega e Dinamarca Bálcãs. Nosso continente México e América Central um América do Sul. Vossência verá se por meio Washington nos poupam tamanha e amarga humilhação. Verificado ela não compreendo Brasil possa dignamente continuar conferência." Telegrama de Rui Barbosa para o Barão de Rio Branco, de três de agosto de 1907. Acervo do Museu do Itamaraty apud LINS, Álvaro. Rio-Branco (O Barão do Rio-Branco): biografia pessoal e história política. 2. ed. São Paulo : Cia. Ed. Nacional, 1965. p. 380 .
} 
Rui Barbosa considerou o projeto flagrantemente contrário ao princípio da igualdade dos Estados. Na sessão de 20 de agosto, apoiando-se em sua inteligência e espírito de justiça, Rui defende esse princípio, opondo-se aos interesses das grandes potências:

"O projeto em questão dá, igualmente, a todos os Estados a faculdade de nomear um dos membros da Corte. No entanto, uma vez nomeado esse membro, há, para os que pertencem a determinados Estados, o direito de fazer parte durante um espaço de tempo mais ou menos curto, enquanto, para outros Estados, o membro designado exercerá suas funções durante o período de duração total.

[...] As condições de exercício não respeitam a igualdade de um direito, senão quando elas são iguais para todos aqueles que as possuem. Ao contrário, a desigualdade no exercício implica na desigualdade no próprio direito, porque o valor de um direito só se mede realmente pela possibilidade jurídica de o exercer.

[...] Existem dois direitos distintos: o de nomear e o de fazer parte. No direito de nomear nós seríamos todos iguais, mas, no direito de fazer parte, nós seríamos absolutamente desiguais. Pois bem, é essa desigualdade que viola a igualdade dos Estados.

[...] Eu termino, Senhores, pedindo-vos desculpas pela vivacidade da minha fala e pela animação da minha voz. É o calor do meu temperamento, inflamado pela sinceridade das minhas convicções. Eu não desejo obstruir, mas eu não posso também abandonar o meu dever." 72

Para as grandes potências, o princípio da igualdade parecia absurdo. Elas não podiam aceitar condições iguais de representação e poder decisório para os países menores, que julgavam ter menos

${ }^{72}$ BARBOSA, Rui. Obras Completas de Rui Barbosa. vol. XXXIV, Tomo II. Rio de Janeiro: Ministério da Educação e Cultura, 1966. pp. 235 à 237. Tradução livre do original em francês, disponível no site:

<http://docvirt.com/docreader.net/docreader.aspx?bib=ObrasRuiMP\&pasta=Vol.\%20XXXIV \%20(1907)\Tomo\%20II\&pesq=\&paglog=>, último acesso em 19 de mar. 2013. 
responsabilidades e interesses. ${ }^{73}$ Como resposta a esses argumentos, Rui Barbosa prontamente diz, em 5 de setembro de 1907:

"O argumento, se ele é verdadeiro, poderia virar uma faca de dois gumes para nossos antagonistas, deixando impossível a criação do projeto americano que os autores sonham que é a perfeição da arbitragem internacional. Porque se os grandes Estados não têm confiança na imparcialidade dos pequenos, os pequenos, por sua vez, poderiam alegar fundadas razões para não acreditar na isenção dos grandes."

O mundo inteiro volta a sua atenção para o discurso do delegado brasileiro e o princípio da igualdade jurídica dos Estados. Os jornais das grandes potências criticam a tese da igualdade, mas os países da América Latina solidarizam-se com ela. William Thomas Stead, conceituado jornalista inglês que cobria os trabalhos da conferência, tornara-se amigo de Rui, e publicava notícias favoráveis à posição brasileira em seu jornal diariamente impresso na Haia. Rui torna-se o líder dos numerosos países que seriam prejudicados pelo projeto da Corte.

Quando as potências perceberam que a tese da igualdade das nações predominava, procuraram Rio Branco e ofereceram um lugar na Corte, entre as grandes potências, para o Brasil. O Barão recusou. Nesse embate entre o Direito e a Força, o Brasil colocou-se ao lado do Direito e não ao lado da Força. Rio Branco alertou Rui Barbosa de que a mesma oferta

73 “'Ao orgulho pessoal e nacional do Barão Marschall ocorreria, por exemplo, esta proposição arrogante: Tenho um grande respeito ao Poder e a quanto ele representa no mundo. Nunca consentirei que uma grande encarnação do Poder como a Alemanha seja julgada por um juiz representante da Guatemala.” LINS, Álvaro. Rio-Branco (O Barão do Rio-Branco): biografia pessoal e história política. 2. ed. São Paulo : Cia. Ed. Nacional, 1965. p. 382.

${ }^{74}$ BARBOSA, Rui. Obras Completas de Rui Barbosa. vol. XXXIV, Tomo II. Rio de Janeiro: Ministério da Educação e Cultura, 1966. p. 304. Tradução livre do original em francês, disponível no site:

<http://docvirt.com/docreader.net/docreader.aspx?bib=ObrasRuiMP\&pasta=Vol.\%20XXXIV \%20(1907)\Tomo\%20II\&pesq=\&paglog=>, último acesso em 19 de mar. 2013. 
poderia ser feita para os demais países da América do Sul. A ordem do Ministro das Relações Exteriores era que o Brasil continuasse defendendo o princípio, seja com o apoio da América do Sul, seja sem nenhum apoio ${ }^{75}$.

Rui alegou que o problema era de uma complexidade muito grande para ser debatido naquela Comissão e, por esse motivo, foi criada uma Comissão Especial, chamada Comissão dos Sete Sábios, composta por Marschall von Bieberstein, da Alemanha; Alexandre Nelidov, da Rússia; Joseph Choate, dos EUA; Léon Bourgeois, da França; Gaëtan Kapos-Mére, do Império Austro-Hungaro; o Conde Tornielli, da Itália; e Rui Barbosa, do Brasil. Por proposta de Rui, foi adicionado Sir Edward Fry, da Inglaterra.

Na Comissão dos Sete Sábios, a vitória de Rui foi absoluta. O projeto inicial foi eliminado. A argumentação de Rui Barbosa venceu os interesses das grandes potências. Reconheceu-se o princípio da igualdade dos Estados e a sua inviolabilidade, instituindo-o de forma definitiva na ordem internacional.

Um novo projeto, tendo por base a representação de todos os países na Corte Permanente de Justiça Arbitral, passa a ser elaborado. O projeto, no entanto, estava destinado ao fracasso. Em ato ofensivo, Marschall von Bieberstein retira-se de férias e Bourgeois deixa a Haia, alegando que não

\footnotetext{
75 "Pois bem, o Brasil poderia ter saído desta Conferência o igual da França, o igual da Inglaterra, o igual dos Estados Unidos. Rui Barbosa empregou o melhor do seu esforço e os tesouros do seu saber para conseguir que dela saia o Brasil, o igual de Nicarágua, o igual de Honduras, o igual de Sião.” Discurso de Léon Bourgeois apud LINS, Álvaro. Rio-Branco (O Barão do Rio-Branco): biografia pessoal e história política. 2. ed. São Paulo : Cia. Ed. Nacional, 1965. p. 386.
} 
havia mais nada a ser feito. Rui passa a ser visto por algumas das grandes potências como o responsável pelo malogro da conferência.

O delegado inglês, Sir Fry, sem querer perder o trabalho realizado, apresenta um projeto de Declaração que sinaliza a urgência da criação da Corte, sem entrar no mérito de sua constituição e funcionamento. Rui, assim como a delegação norte-americana, aceita a proposta.

Em seu último discurso, Rui Barbosa defende-se daqueles que o responsabilizavam pelo insucesso da Corte Permanente de Justiça Arbitral. Ressalta que foi só para a grande aspiração geral da paz que o Brasil trabalhou, quando opôs-se "ao triunfo da desigualdade" na composição do Tribunal. Recorda, ao final, - com a visão de um sábio, que alcança além dos séculos -, que as diferenças de grandeza entre os países da Europa e os da América são acidentais, e que no futuro, poderiam inverter-se:

"Por que nós resistimos? [...] Existe, sem dúvida, entre os Estados, como entre os indivíduos, diversidades de cultura, de honestidade, de riqueza e de força. Mas será que isso resulta em uma diferença qualquer no que diz respeito aos seus direitos essências? Os direitos civis são os mesmos para todos os homens. Os direitos políticos são os mesmos para todos os cidadãos. Lord Kelvin ou Mr. John Morley têm a mesma voz para a eleição do augusto parlamento soberano da Grã-Bretanha que um operário embrutecido pelo trabalho e pela miséria. Será que, todavia, a capacidade intelectual e moral desse trabalhador braçal, rebaixado pelo sofrimento e pelo esforço, é igual àquela do homem de Estado ou do instruído? Pois bem: a soberania é o direito elementar por excelência dos Estados constituídos e independentes. Ora, soberania quer dizer igualdade. Na ideia, como na prática, a soberania é absoluta. Ela não admite graus. Mas a distribuição jurisdicional do direito é um dos ramos da soberania. Assim, se é necessário existir, entre os Estados, um órgão comum de justiça, necessariamente, todos os Estados devem ter uma representação equivalente.

[...] Não é uma obra da razão, do direito e da realidade? Àqueles que duvidam, nós respondemos com os mestres menos idealistas da literatura do Direito Internacional. Pegai, por exemplo, o major-general Halleck do exército americano, cuja obra se distingue pela frieza e pelo realismo de seu espírito. Ele vos dirá: 
"Todos os Estados soberanos, qualquer que seja a sua força relativa, são iguais aos olhos do Direito Internacional, são dotados, naturalmente, dos mesmos direitos, vinculados pelos mesmos deveres, submetidos a obrigações equivalentes. As diferenças de grandeza não implicam em nenhuma distinção jurídica. Uma inferioridade intelectual, seja ela acidental ou permanente, não dá uma superioridade qualquer de direito ao vizinho mais forte e todas as vantagens que ele apodera sobre esse título, não será nada mais que uma usurpação. Essa é a grande lei fundamental do Direito Público, que importa à paz do gênero humano, seja na ordem privada, seja na ordem política, manter inviolavelmente."

É, então, um homem de espada, cujo livro, de um positivismo rígido e acerado, não é suspeito de fraqueza humanitária ou de sensibilidade pacifista. É ele que proclama que na igualdade dos Estados está a condição primordial da paz entre as nações. Assim, foi só para a grande aspiração geral da paz que nós trabalhamos, quando opusemo-nos com todas as nossas forças ao triunfo da desigualdade na composição do Tribunal de Arbitragem Internacional.

[...] O Japão entrou ao concerto europeu pela porta da guerra, forçando sua entrada com a espada. Nós, os Estados da América Latina, fomos convidados a entrar aqui pela porta da paz. Nós passamos pelos umbrais nessa Conferência e vos começais a nos conhecer como obreiros da paz e do direito. Mas se nós nos encontramos decepcionados, se nos despedirem desiludidos, com a experiência de que a grandeza internacional só se mede pela força das armas, então, por obra vossa, o resultado da Segunda Conferência da Paz seria de inverter a corrente política do mundo para o sentido da guerra, forçando nos a procurar nos grandes exércitos e nas grandes marinhas o reconhecimento da nossa posição, inutilmente indicada pela população, pela inteligência e pela riqueza.

Será que não conseguiríamos? Não se deve menosprezar. Essas diferenças de grandeza entre os países da Europa e os da América são bem acidentais.

[...] Ora, para os eventos que compõem a história, o que vem a ser o espaço de tempo entre uma ou duas gerações? No movimento do mundo, não é nada mais do que o espaço de um dia para outro dia. Por que, então, falar, com tanto prazer, de fracos e fortes, de pequenos e grandes entre as nações? Nesses tempos, a madureza cuida-se, para os povos, na adolescência. No decorrer dessa era acelerada, o porvir invade o presente; no entanto o futuro é sempre cheio de inversões e surpresas." 76

${ }^{76}$ BARBOSA, Rui. Obras Completas de Rui Barbosa. vol. XXXIV, Tomo II. Rio de Janeiro: Ministério da Educação e Cultura, 1966. pp. 383, 389, 393, 394. Tradução livre do original em francês, disponível no site:

<http://docvirt.com/docreader.net/docreader.aspx?bib=ObrasRuiMP\&pasta=Vol.\%20XXXIV \%20(1907)|Tomo\%20II\&pesq=\&paglog=>, último acesso em 19 de mar. 2013. 
Ao terminar, é ovacionado de forma nunca antes vista pela Conferência. Rui Barbosa e o Brasil, que antes eram figuras obscuras para a sociedade internacional, consagram-se na história do Direito Internacional como os defensores da igualdade dos Estados, deixando às gerações futuras um sólido antecedente a que poderão sempre recorrer. 


\section{CAPÍTULO 4 - O LEGADO DE RUI BARBOSA PARA UMA ORDEM MUNDIAL DEMOCRÁTICA}

Como consequência dos feitos alcançados durante a Conferência, Rui Barbosa foi condecorado em 1908 pelo Presidente da República, Afonso Pena. Em 1923, foi convidado pelo Presidente Artur Bernardes para assumir o cargo de Ministro das Relações Exteriores, cargo que nunca pode aceitar, pois viria a falecer pouco depois, em março daquele ano.

Na Haia, no Palácio da Paz, sede da Corte Permanente de Arbitragem e da Corte Internacional de Justiça, encontram-se bustos de seletos personagens históricos que marcaram o Direito Internacional e a luta pela paz universal, como Hugo Grocius, Carlos Calvo, Andrew Carnegie, Mahatma Gandhi, Jean Monnet e Nelson Mandela. Entre eles está também o busto de Rui Barbosa, imortalizado ao lado da mais completa biblioteca de Direito Internacional do mundo. Cabe ressaltar que essa não foi a única homenagem feita ao defensor do princípio da igualdade dos Estados na Haia, pois há um retrato de Rui pintado por Portinari na sala dos juízes da Corte Internacional de Justiça.

Hodiernamente, a luta pelo princípio da igualdade entre os Estados e pela democratização da Ordem Mundial continua a ser empreendida pelo Brasil, principalmente no que se refere à reforma do Conselho de Segurança das Nações Unidas.

O Conselho de Segurança é o principal órgão protetor da paz e da segurança internacionais. Esse órgão possui posição de destaque na Ordem Mundial, pois a Carta das Nações Unidas confere ao Conselho de 
Segurança, em seu capítulo VII, competência para autorizar o uso da força em caso de ameaça à paz e à segurança internacionais.

Trinta e oito anos após a Conferência de 1907, a Carta de São Francisco, que cria a Organização das Nações Unidas, viola o princípio da igualdade entre os Estados soberanos. Embora reconheça esse princípio no art. $2^{\circ}, \mathrm{I}$, a Carta o contraria a seguir, ao estabelecer no Conselho de Segurança flagrante desigualdade entre as potências vencedoras da Segunda Guerra Mundial e os demais países membros da ONU. O Conselho de Segurança, conforme o art. 23 da Carta das Nações Unidas, é integrado por quinze membros: dez deles são eleitos para mandatos de dois anos, sem possibilidade de reeleição imediata, e os cinco restantes são membros permanentes: China, Estados Unidos, França, Reino Unido e Rússia. ${ }^{77}$ Os cinco membros permanentes possuem, ademais, o direito exclusivo de vetar qualquer proposta de decisão do Conselho (art. 27, III).

Essa estrutura claramente desrespeita o princípio da igualdade dos Estados, tendo em vista que exclui regiões inteiras do mundo, principalmente do mundo em desenvolvimento, como a América Latina e a África. Essa falta de representatividade enfraquece a atuação do Conselho de Segurança, pois gera insatisfações e dúvidas quanto à legitimidade e à

77 "Muitos aqui sabem que na Conferência de Dumbarton Oaks, que preparou o primeiro projeto da Carta de São Francisco, em Agosto de 1944, a delegação dos Estados Unidos, por instrução do Presidente Roosevelt, propôs o acréscimo de um sexto assento permanente no Conselho de Segurança. Como nos conta em suas memórias o ex-Secretário de Estado Cordell Hull, esse assento permanente caberia ao Brasil devido a seu tamanho, população, recursos e participação ativa na guerra. A configuração geopolítica do pós-guerra não permitiu que a proposta norte-americana avançasse. Mas o fato de que o brasil tivesse sido lembrado naquele momento é por si só expressivo.” AMORIM, Celso. A diplomacia multilateral do Brasil: um tributo a Rui Barbosa. Brasília: Fundação Alexandre de Gusmão, 2007. 9 p. 
eficácia de seus atos, ameaçando a segurança e a paz da sociedade internacional $^{78}$. Por esse motivo, e recordando o legado de Rui Barbosa na Haia, o Brasil considera a reforma do Conselho de Segurança inadiável.

Hodiernamente, são cinco os principais grupos de países que defendem a reforma do Conselho de Segurança da ONU: G-4; Uniting for Consensus (UfC); L.69 (grupo de países em desenvolvimento); C-10 (grupo africano); e Small-5. O Brasil integra o G-4, desde setembro de 2004, junto com a Alemanha, a Índia e o Japão ${ }^{79}$.

O Brasil defende uma expansão do Conselho de Segurança por meio do ingresso de novos membros permanentes e não-permanentes. A representatividade absoluta de todos os países integrantes da ONU seria o ideal, mas é impraticável, tendo em vista que o órgão precisa ser capaz de tomar decisões de forma rápida para ser eficiente ${ }^{80}$. Para o Brasil, a reforma não deve ser conclusiva. Em outras palavras, o País defende que o órgão passe, dentro de um período razoável, por outras revisões. Os novos

\footnotetext{
78 "Estão excluídas do centro decisório, nessa matéria, regiões inteiras do mundo, como a América Latina e a África. Uma estrutura de governança que não seja representativa gera frustração, dúvidas e questionamentos quanto à legitimidade e, portanto à eficácia, de seus atos. $\mathrm{O}$ maior risco que corremos é o de esfacelamento da credibilidade do CSNU, minando sua capacidade de lidar com as graves ameaças à paz. Perderemos todos se as novas crises internacionais acabarem tratadas por coalizões de países à margem do órgão ou sem respaldo no direito internacional." PATRIOTA, Antônio de Aguiar. Hora de Reformar. O Globo. Rio de Janeiro, 28 de abril de 2013.

${ }^{79}$ O Brasil e o Japão são os membros que ocuparam mais vezes um assento não-permanente no Conselho de Segurança.

80 "Naturalmente, é difícil conciliar o ideal democrático em sua forma mais pura, que inspirava o pensamento de Rui Barbosa, e a necessidade de um órgão com capacidade de decisão rápida e eficaz em temas que exigem soluções muitas vezes em caráter de urgência, como são os da paz e segurança internacionais." AMORIM, Celso. A diplomacia multilateral do Brasil: um tributo a Rui Barbosa. Brasília: Fundação Alexandre de Gusmão, 2007. 12 p.
} 
membros permanentes não disporiam do direito de veto que deve ser eliminado, ou pelo menos atenuado, de forma gradual ${ }^{81}$.

A crise econômica de 2008 demonstrou o peso dos países em desenvolvimento, como o Brasil e a Índia, e o obsoletismo das estruturas do plano econômico-financeiro, o que resultou na reestruturação de cotas no FMI e no fortalecimento do G-20. De igual maneira, a reforma no plano da segurança e paz internacionais é indispensável, tendo em vista, por exemplo, que os países em desenvolvimento são imprescindíveis contribuintes de tropas para as operações de manutenção da paz $(90,7 \%$ do total de tropas e policiais) $)^{82}$.

A ONU, que em sua concepção reunia 51 países, tem hoje 193 membros. Passados sessenta e oito anos do fim da Segunda Guerra Mundial e terminada a Guerra Fria, surgiram novos desafios globais como o terrorismo e a ação de atores não estatais em conflitos internos. A estrutura do Conselho de Segurança, todavia, foi alterada apenas uma vez, em 1965, com o aumento de assentos não permanentes de seis para $\mathrm{dez}^{83}$. Os

\footnotetext{
${ }^{81}$ Nesse sentido, veja-se: "Tampouco devemos ter a pretensão de legislar para a eternidade. É necessário que a reforma por que venha a passar o Conselho de Segurança esteja sujeita a uma revisão sem pré-julgamentos, dentro de um período razoável. Obviamente, novos membros permanentes não devem dispor do direito de veto, mecanismo por cuja eliminação gradual e/ou atenuação continuaremos a militar, dentro dos limites do realismo." AMORIM, Celso. A diplomacia multilateral do Brasil: um tributo a Rui Barbosa. Brasília: Fundação Alexandre de Gusmão, 2007. 12 p.

${ }^{82}$ Dados retirados do sítio eletrônico oficial da ONU:

http://www.un.org/en/peacekeeping/resources/statistics/contributors.shtml> Último acesso em 26 mai. 2013.

${ }^{83}$ Nesse sentido, veja-se: “A reforma da ONU não estará completa tampouco sem a expansão e a atualização do seu Conselho de Segurança, cujos membros permanentes seguem sendo os mesmos de seis décadas atrás. Desde 1945, o número de Estados-membros quase quadruplicou, com acentuado aumento no número de países em desenvolvimento." AMORIM, Celso. A
} 
membros permanentes, em particular EUA, China e Rússia, apesar de admitirem a necessidade de uma reforma, procuram atrasar qualquer tipo de negociação.

A decisão $n^{\circ}$ 62/557, de 15/09/2008, iniciou as negociações intergovernamentais sobre a reforma do Conselho de Segurança no Plenário da Assembleia Geral das Nações Unidas. Nessas negociações, a grande maioria dos Estados membros vem mostrando-se favorável a uma expansão do Conselho, tanto nos assentos permanentes, como nos assentos nãopermanentes $^{84}$.

Os chanceleres do $\mathrm{G} 4$, em reunião à margem da $67^{\mathrm{a}}$ Sessão da Assembleia Geral das Nações Unidas, em 25 de setembro de 2012, emitiram Declaração em que reiteraram seu compromisso com a reforma do Conselho de Segurança. Cada membro aspira a ocupar um assento permanente no Conselho reformado e apoia a candidatura de seus pares ${ }^{85}$. Os chanceleres de Brasil, Alemanha, Japão e India também reafirmaram, na

diplomacia multilateral do Brasil: um tributo a Rui Barbosa. Brasília: Fundação Alexandre de Gusmão, 2007. 12 p.

${ }^{84}$ Nesse sentido, veja-se: "The Ministers discussed the progress on Security Council reform achieved thus far, including the discussions held during the eighth round of the intergovernmental negotiations. In this context, the Ministers shared the assessment that an overwhelming majority of member states voiced support for an expansion of the Security Council in both categories of membership, permanent and non-permanent. The Ministers also noted the assessment made to that end by the Chairman of the intergovernmental negotiations, H.E. Ambassador Zahir Tanin, in his letter dated 25 July 2012 to the President of the General Assembly and welcomed his recommendations therein." Nota à Imprensa nº 230 de 2012 do Ministério das Relações Exteriores.

${ }^{85}$ Hodiernamente, o Brasil recebe o apoio de dois membros permanentes: Reino Unido e França. Além disso, dos membros da ONU, 89 já declararam apoio ao Brasil. Informação retirada do sítio eletrônico oficial do Itamaraty: http://www.itamaraty.gov.br/temas/balanco-de-politicaexterna-2003-2010/3.1.2-reforma-da-governanca-global-reforma-do-conselho-de-seguranca Último acesso em 26 de mai. de 2013. 
Declaração, a importância de assegurar a representação da África nos assentos permanentes de um novo Conselho. ${ }^{86}$

O trabalho de Rui Barbosa na Segunda Conferência de Paz da Haia marcou a história do Direito Internacional ao demonstrar às grandes potências o papel necessário dos países mais fracos na elaboração do Direito das Gentes. Decorridos cento e seis anos da realização da Conferência, o Brasil enfrenta desafio muito semelhante na reforma do Conselho de Segurança da ONU, mas, desta vez, tem a seu favor importante precedente histórico.

86 "The G4 countries reiterated their commitments as aspiring new permanent members of the UN Security Council, as well as their support for each other's candidatures. They also reaffirmed their view of the importance of Africa to be represented in the permanent membership of an enlarged Council.” Nota à Imprensa n 230 de 2012 do Ministério das Relações Exteriores. 


\section{CONCLUSÃO}

A Conferência de Paz da Haia de 1907 representa um ponto de inflexão na formação da sociedade internacional e do Direito Internacional. Ela foi um verdadeiro parlamento dos povos que consagrou o universalismo e o princípio da igualdade dos Estados. Apesar de não ter criado nenhum tribunal internacional, o estatuto da Corte Permanente de Justiça Arbitral, nela esboçado, serviu de base para o atual estatuto da Corte Internacional de Justiça.

Em plena corrida armamentista do início do século XX, época em que as nações mediam-se pela capacidade bélica, a figura do delegado brasileiro cresceu no decorrer da Conferência, angariando respeito internacional ao Brasil. Rui Barbosa conseguiu, por meio da palavra, fazer que as potências imperialistas respeitassem o princípio da igualdade jurídica dos Estados.

A vitória desse princípio na Conferência possui grande relevância para a luta por uma ordem mundial democrática, em que todos os Estados possuam os mesmos direitos e deveres. Hoje, essa luta prossegue, principalmente, nos esforços que o Brasil e outros países empregam para reformar o Conselho de Segurança das Nações Unidas, de modo a torna-lo um órgão mais representativo da sociedade internacional atual.

A defesa dos ideais de igualdade e de paz mundiais, o amor à pátria e os argumentos apresentados por Rui Barbosa devem servir como inspiração. A coragem com que enfrentou sozinho as grandes potências, para defender o Brasil e as próprias causas em que intimamente acreditava, foi o grande ensinamento deixado por Rui Barbosa para os brasileiros, hoje e sempre. 


\section{BIBLIOGRAFIA}

ACCIOLY, Hildebrando Pompeu. Manual de Direito Internacional público. 19. ed. São Paulo: Saraiva, 2011. 976 p.

ALENCAR, José Almino de; SANTOS, Ana Maria Pessoa dos. Meu caro Rui, meu caro Nabuco. Rio de Janeiro: Casa de Rui Barbosa, 1999. $94 \mathrm{p}$.

AMARAL, Márcio Tavares d'. Rui Barbosa. São Paulo : Ed. Três, 2003. 280 p.

AMORIM, Celso. A diplomacia multilateral do Brasil: um tributo a Rui Barbosa. Brasília: Fundação Alexandre de Gusmão, 2007. 21 p.

BARBOSA, Rui. A Conferência de Haia: dois autógrafos do arquivo da Casa de Rui Barbosa. Rio de Janeiro: Casa de Rui Barbosa, 1952. p. 79.

BARBOSA, Rui. Obras Completas de Rui Barbosa. vol. XXXIV, Tomo II. Rio de Janeiro: Ministério da Educação e Cultura, 1966. p. 405.

BUENO, Clodoaldo. CERVO, Amando Luiz. História da política exterior do Brasil. 3 ed. Brasília: Ed. UnB, 2008. 559 p.

BULL, Hedley. A sociedade anárquica: Um estudo da ordem na política mundial. Brasília: Editora Universidade de Brasília, Instituto de Pesquisa de Relações Internacionais; São Paulo: Imprensa Oficial do Estado de São Paulo, 2002. 361 p. 
BULL, Hedley; WATSON, Adam. The Expansion of international society. Oxford : Clarendon Press, c1984. 479 p.

CARDIM, Carlos Henrique. A Raiz das Coisas: Rui Barbosa: O Brasil no Mundo. Rio de Janeiro: Civilização Brasileira, 2008. 350 p.

FIHO, Luiz Viana. A vida do Barão do Rio Branco. Rio de Janeiro : J. Olympio, 1959. 459 p.

LINS, Álvaro. Rio-Branco (O Barão do Rio-Branco): biografia pessoal e história política. 2. ed. São Paulo : Cia. Ed. Nacional, 1965.

MAGALHÃES, Rejane M. Moreira de A.. Presença de Rui Barbosa em Haia. Disponível em http://www.casaruibarbosa.gov.br/dados/DOC/artigos/sobre rui barbos a/FCRB_RejaneMagalhaes_PresencaRuiBarbosa_em_Haia.pdf. Acesso em 13 de mar. 2013.

MELLO, Celso D. de Albuquerque. Curso de Direito Internacional público. 14. ed. v.1. Rio de Janeiro : Renovar, 2002. 893 p.

REZEK, Jose Francisco. Direito Internacional público: curso elementar. 10. ed.. São Paulo: Saraiva, 2005. 415 p.

VISENTINI, Paulo Fagundes. "A Águia de Haia": Rui Barbosa Diplomata. In: NAGLE, Marilene; WIESEBRON, Marianne L. (Orgs.). Rui Barbosa: uma personalidade multifacetada. Brasília: FUNAG, 2012. p. $49-57$. 


\section{ANEXOS}
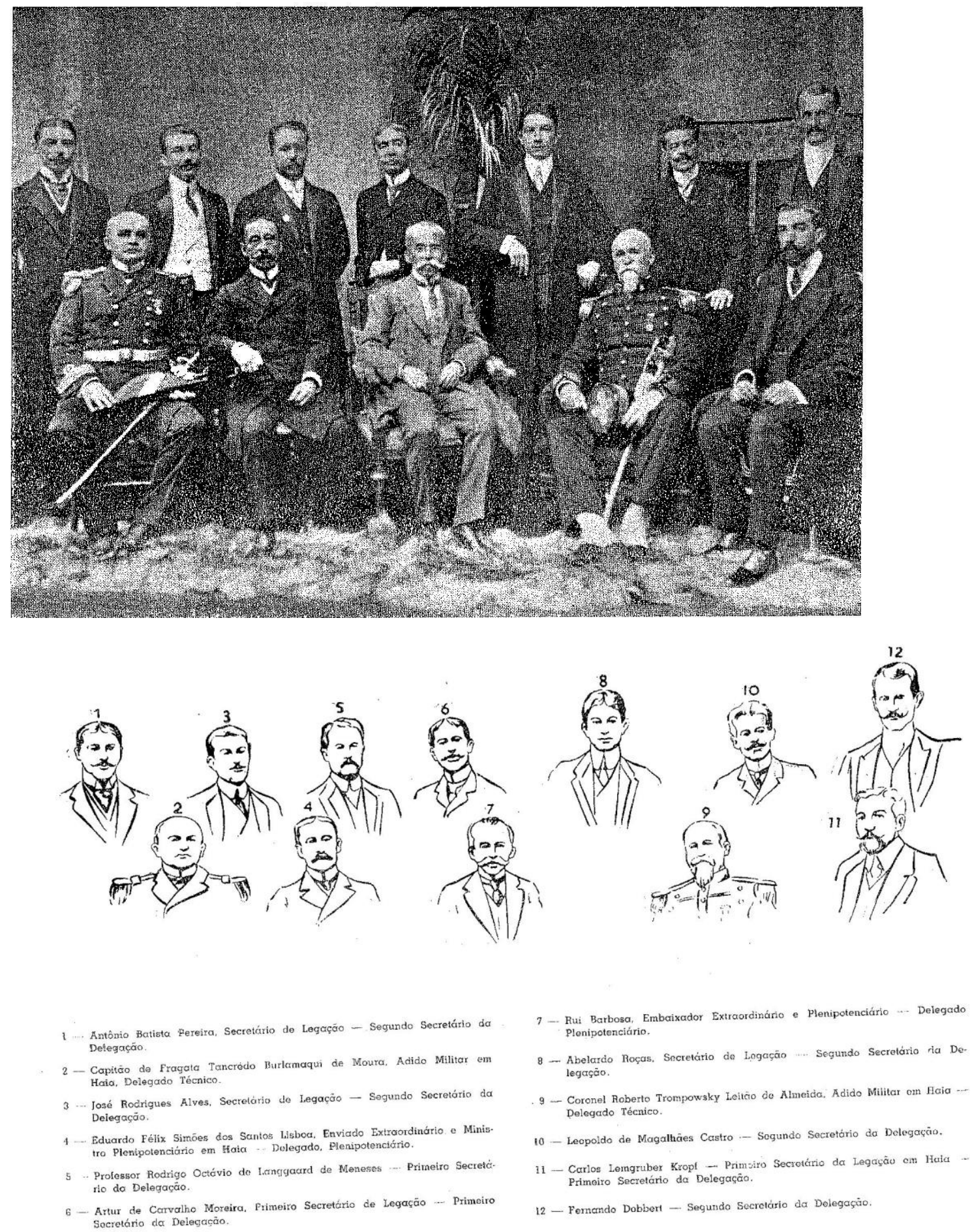

Figura 1 Delegação brasileira. BARBOSA, Rui. A Conferência de Haia: dois autógrafos do arquivo da Casa de Rui Barbosa. Rio de Janeiro: Casa de Rui Barbosa, 1952. p. 12. 


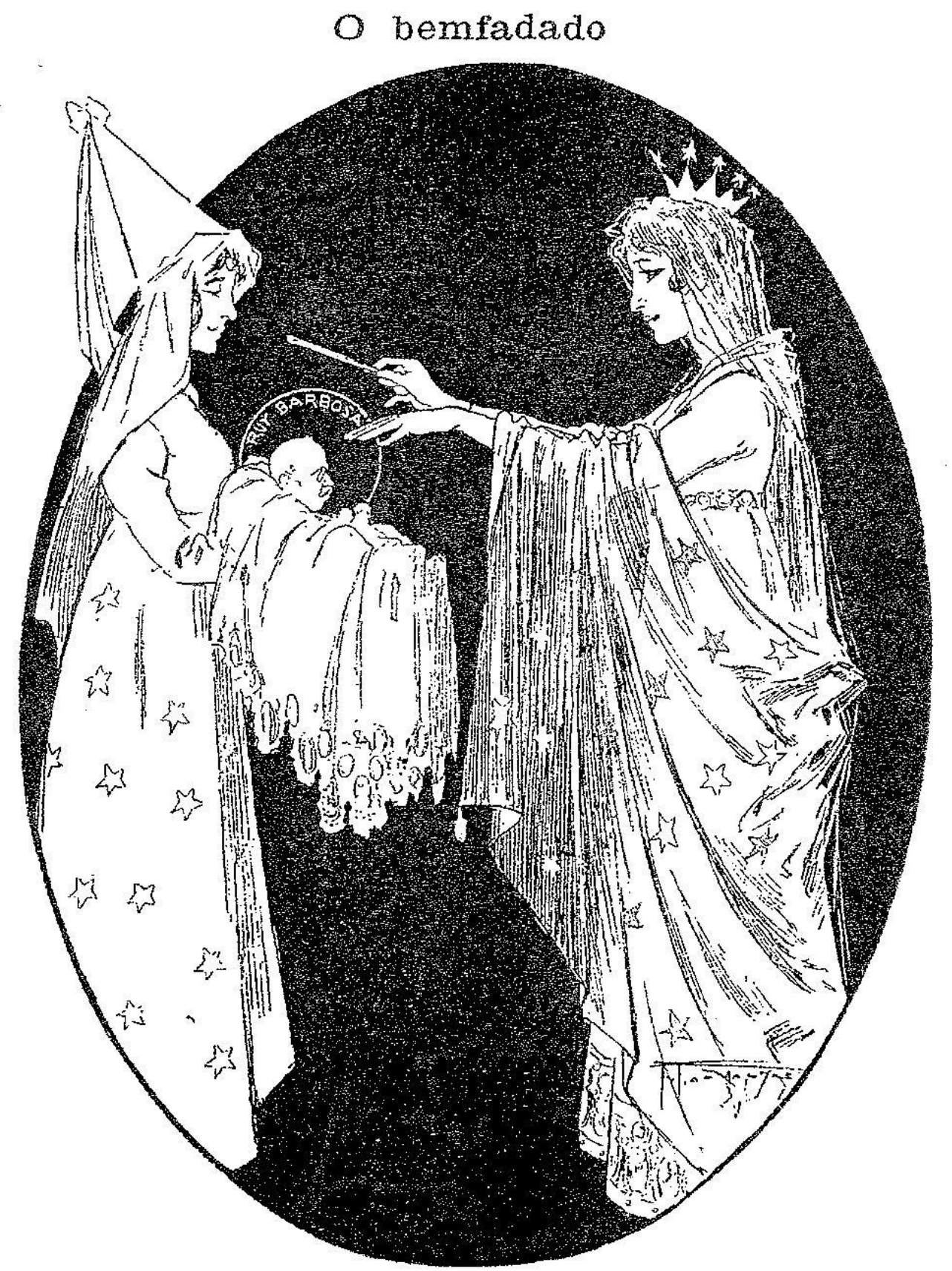

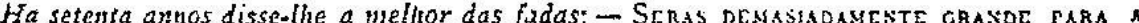

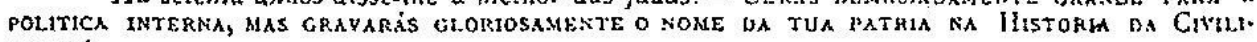
SAFAO:

Figura 2 Charge de Rui. Arquivo da Fundação Casa de Rui Barbosa. 


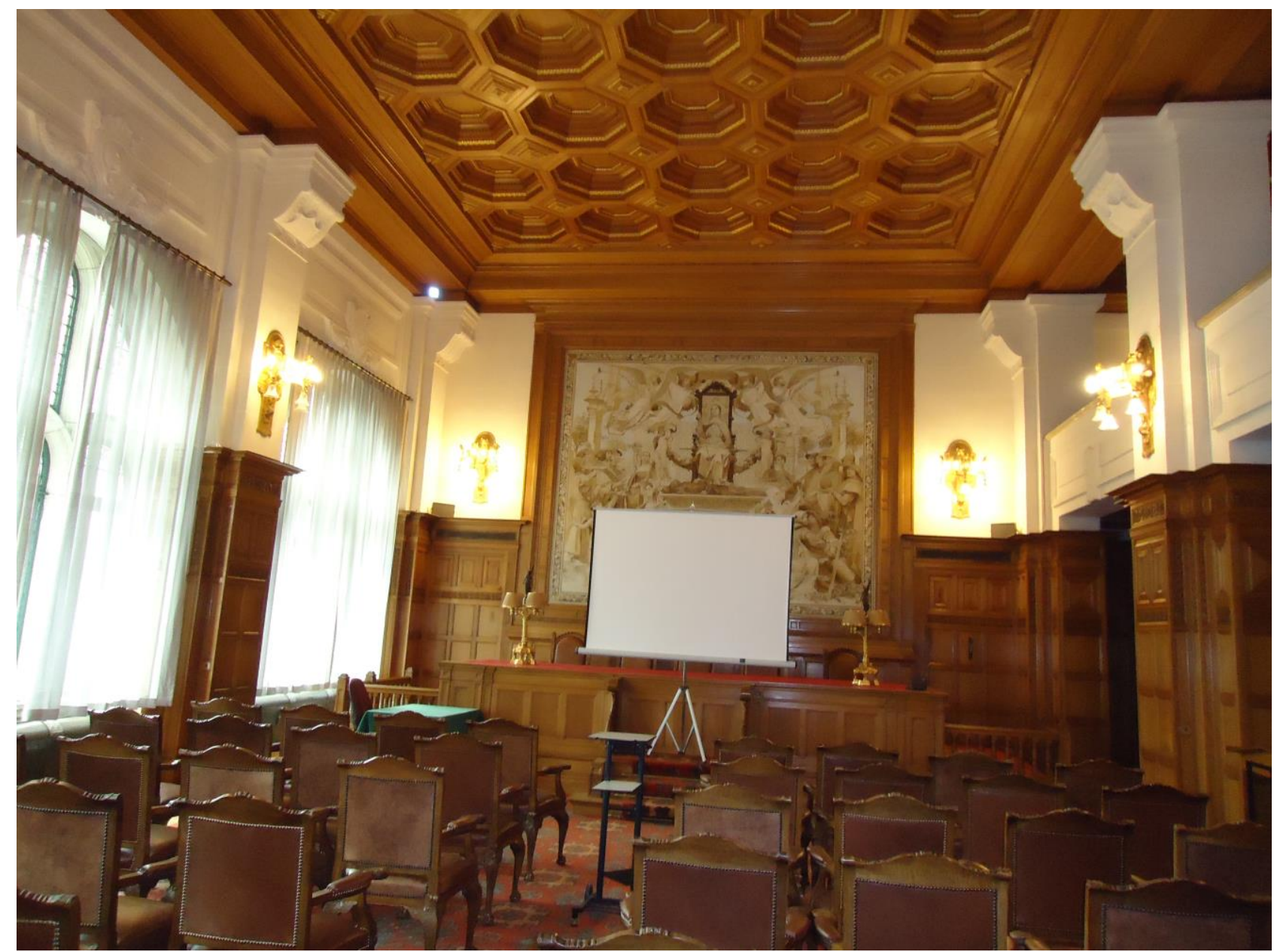

Figura 3 Sala de audiências da Corte Permanente de Arbitragem no Palácio da Paz na Haia. Foto de Nádia de Araújo. 


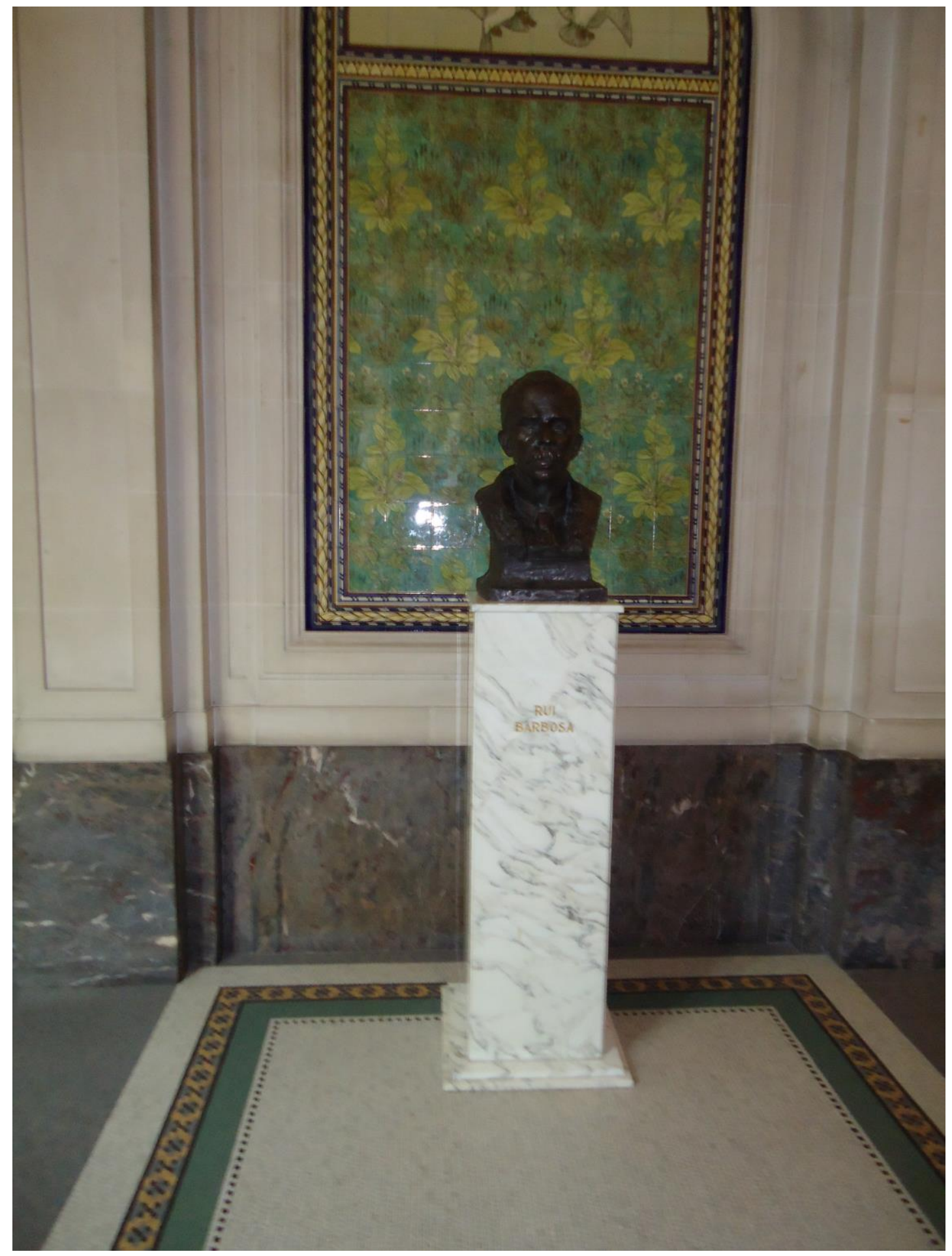

Figura 4 Busto de Rui Barbosa no Palácio da Paz na Haia. Foto de Nádia de Araújo. 